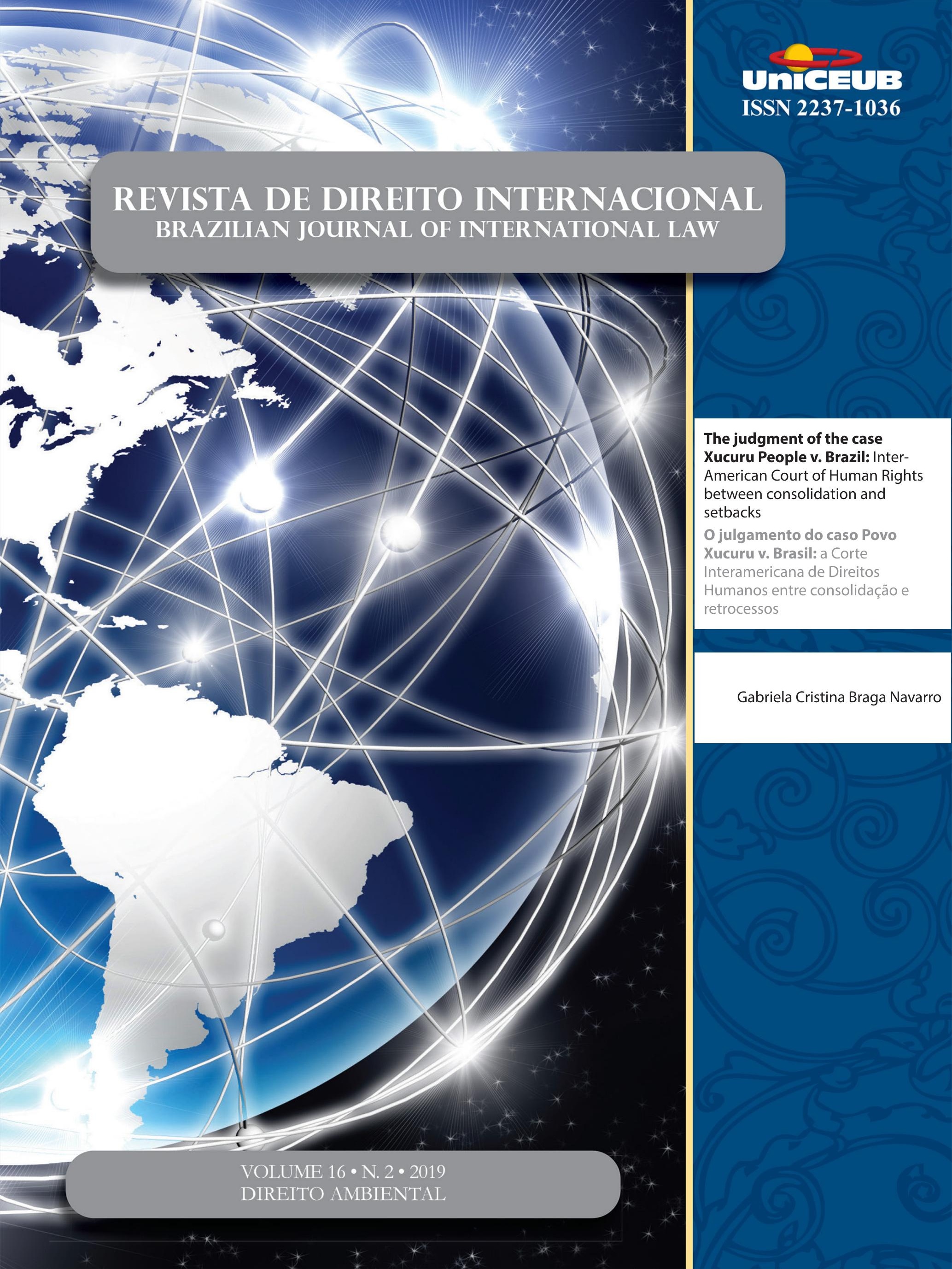




\section{Sumário}

I. Crônicas do Direito Internacional .................................................1

AMAZONIE: LE DROIT INTERNATIONAL EN VIGUEUR APPORTE DES RÉPONSES SUBSTANTIELLES ... 3 Pierre-Marie Dupuy

A eVOluÇão da SOluÇão DE CONTROVÉRSias NOS ACFIs 8 Ana Rachel Freitas da Silva

II. Dossiê Especial: Direito ambientai 14

A brief overview of Sustainable DeVelopment: HOW A DEBATEd CONCEPT With A MUCH-CONTESTED LEGAL NATURE COULD PERFORM A VALUABLE ROLE IN THE DECISION-MAKING ......16 Natali Francine Cinelli Moreira

A meta 11 de Aichi e as Áreas marinhas protegidas em grande ESCALA: proteção ambienTAL OU OPORTUNISMO POLÍTICO?

Alexandre Pereira da Silva

LITIGÂNCIA CLIMÁTICA COMO ESTRATÉGIA JURISDICIONAL AO AQUECIMENTO GLOBAL ANTROPOGÊNICO E MUDANÇAS CLIMÁTICAS

Délton Winter de Carvalho e Kelly de Souza Barbosa

AsSESSMENT AND CHALlENGES OF CARBON MARKETS

Louise Pigeolet e Arnaud Van Waeyenberge

As abordagens dos países da América Latina e Caribe sobre a mobilidade humana proVOCADA PELAS MUDANÇAS CLIMÁTICAS

Diogo Andreola Serraglio e Heline Sivini Ferreira

Implementation of Legal mechanisms of environmental protection by the South PaCIFIC REGIONAL ORGANIZATIONS 116 Joanna Siekiera 
CONCILIATING THE OVERLAP OF PROTECTED AREAS AND TRADITIONAL TERRITORIES: LEGAL INNOVATIONS FOR BIOLOGICAL DIVERSITY CONSERVATION IN BRAZILIAN PARKS

Nathalia Fernandes Lima e Solange Teles Silva

O USO DE DRONES COMO INSTRUMENTO PARA A CONSERVAÇÃo DA BIODIVERSIDADE NO BRASIL141 Larissa Suassuna Carvalho Barros e Marcia Dieguez Leuzinger

Agrotóxicos e direitos humanos no contexto global: o Brasil EM Risco de Retrocesso?

Marcelo Pretto Mosmann, Letícia Albuquerque e Isabele Bruna Barbieri

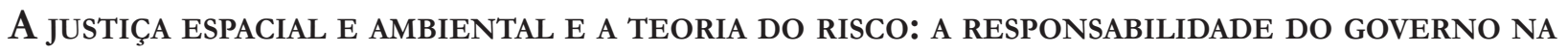
PREVENÇÃo CONTRA DESASTRES (NO BRASIL). 169

José Adércio Leite Sampaio e Edson Rodrigues de Oliveira

The judgment of the case Xucuru People v. Brazil: Inter-American Court of Human RigHTS BETWEEN CONSOLIDATION AND SETBACKS

Gabriela Cristina Braga Navarro

II. Artigos sobre outros temas

NACIONALIDADE: NOVAS REGRAS, VELHOS PROBLEMAS

226

Paulo Henrique Faria Nunes

O EXERCíCIO DA JURISDIÇÃO INTERAMERICANA DE DIREITOS HUMANOS: LEGITIMIDADE, PROBLEMAS E POSSÍVEIS SOLUÇÕES

Felipe Grizotto Ferreira, Guilherme Perez Cabrale Lucas Catib de Laurentiis

A proteção da identidade de gênero na jurisprudênCia da Corte Europeia de Direitos Humanos

Gabriel Coutinho Galil

O COMITÊ JURÍdico INTERAMERICANO dA OEA E A CODIFICAÇÃo DO DIREITO INTERNACIONAL REGIONAL. 
O caso Petruhhin e o princípio do nível mais elevado de proteção no tocante aos diREITOS FUNDAMENTAIS NO ÂMBITO DA UNIÃo EUROPEIA............................................304

Clovis Demarchi e Jaine Cristina Suzin

A AUTONOMia da VONTADE NA ESCOLHA dA LEI APLICÁVEl AOS CONTRATOS DE COMÉRCiO INTER-

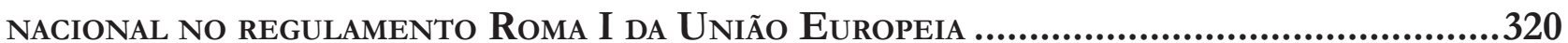

Aline Beltrame de Moura e Rafaela Hörmann

A JuRisdição da ICANN: desafios atuais e Prospectivas futuras...............................335 Aziz Tuffi Saliba e Amael Notini Moreira Bahia

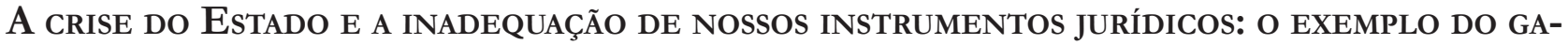
RANTISMO PENAL NO BRASIL.

Oswaldo Poll Costa e Francisco Quintanilha Veras Neto

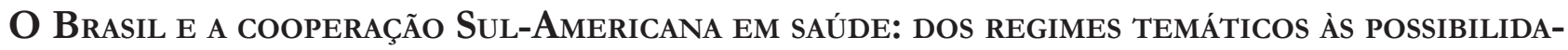
DES DE EFETIVAÇÃo ESTRUTURANTE

Ademar Pozzatti Junior e Luiza Witzel Farias

III. RESENHAS

Resenha da obra: SILVA, Waldimeiry Correa da. Regime internacional de enfrentaMENTO AO TRÁFICO DE PESSOAS: AVANÇOS E DESAFIOS PARA A PROTEÇÃo DOS DIREITOS HUMANOS. Rio de Janeiro: Lumen Juris, 2018. 385

Mércia Cardoso de Souza e Guirino Nhatave 


\title{
The judgment of the case Xucuru People v. Brazil: Inter-American Court of Human Rights between consolidation and setbacks*
}

\author{
O julgamento do caso Povo Xucuru v. Brasil: \\ a Corte Interamericana de Direitos Humanos \\ entre consolidação e retrocessos
}

Gabriela Cristina Braga Navarro**

\section{Abstract}

The present article aims to analyse the recent decision against Brazil issued by the Inter-American Court of Human Rights, the Xucuru indigenous people and its members v. Brazil, which was decided in February 2018. The decision is the most recent among the consolidated jurisprudence of the Court on indigenous peoples rights, as well as the first one against Brazil. The case study is based mainly upon a bibliographic review of primary sources related to the case, as well to the Court's jurisprudence on indigenous rights. To achieve the central objective, the article is composed of three sections: an analysis of the Court's jurisprudence on indigenous territorial rights, a further analysis of the decision on the Xucuru case and, finally, an analysis of aspects that were absent in the decision. The article concludes that, in most aspects, the judgment consolidates the Court case law on the territorial protection of indigenous lands. However, the decision is considered flawed in regard to four aspects: the protection of human rights defenders, the mentioning of the American Declaration on the Rights of Indigenous Peoples, applied remedies and the recognition of the injured party. As the case is very recent, this is the first academic analysis on its content. The Court's innovative jurisprudence on indigenous rights must be acknowledged, but flaws and limitations in the most recent decision must be pointed out and analysed in order to enable further development and, therefore, provide a most adequate human rights protection.

Keywords: Inter-American System of Human Rights. Indigenous rights. Case analysis. Xucuru case.

* Recebido em 15/03/2019 Aprovado em 24/06/2019

** Doutoranda em Direito na Johann Wolfgang Goethe Universität (Alemanha). Professora assistente no Departamento de Direito da Universidade Federal de Lavras. Mestre em Direito pela Universidade Federal de Santa Catarina. E-mail: gabrielabnavarro@gmail.com

\section{Resumo}

O presente artigo almeja analisar a recente decisão emitida pela Corte Interamericana de Direitos Humanos contra o Brasil, Povo Indígena Xucuru e seus membros v. Brasil, julgado em fevereiro de 2018. A decisão é a mais recente entre a consolidada jurisprudência da Corte em direitos indígenas, assim como primeira contra o Brasil. O estudo de caso está baseado principalmente em revisão bibliográfica de fontes primárias relacionadas ao caso, 
assim como à jurisprudência da Corte na temática. Para atingir o objetivo central, o presente artigo encontra-se dividido em três seções: análise da jurisprudência anterior da Corte em direitos indígenas, análise da decisão no caso Xucuru e, por fim, análise de elementos ausentes da decisão. $\mathrm{O}$ artigo conclui que o julgamento em sua maioria consolida a jurisprudência da Corte sobre direitos territoriais indígenas. Contudo, o artigo conclui que a decisão apresenta falhas em relação a quatro aspectos: proteção de defensores de direitos humanos, menção à Declaração Americana de Direitos dos Povos Indígenas, medidas de reparação aplicadas e reconhecimento de partes lesionadas. Como se trata de decisão recente, este é o primeiro trabalho acadêmico a analisar seu conteúdo. A inovadora jurisprudência da Corte em matéria indígena deve ser reconhecida, mas falhas e limitações devem ser apontadas e analisadas em sua decisão mais recente objetivando-se possibilitar futuro desenvolvimento e, assim, oferecer uma proteção de direitos humanos mais adequada.

Palavras-chave: Sistema Interamericano de Direitos Humanos. Direito indígena. Análise de caso. Caso Xucuru.

\section{Introduction}

Traditional territories are, for indigenous peoples, the immanent source for food, housing, medicine, religion and cultural practices. However, continuing centuries of colonial dispossession, traditional peoples still struggle to have full control over their lands, even though land rights are a reality in most American legal systems. In the last few years, threats against them have multiplied and intensified, provoked mainly by pressure over natural resources and extensive infrastructure projects, leading to a considerable increase in violence against indigenous members. Strategic litigation has become a last resource in this battle, understood as the most viable way to implement their rights. Therefore, it is of central importance that strategic litigation offers an adequate solution for the indigenous demands, redressing centuries of social marginalization ${ }^{1}$.

Supra-national strategic litigation was the path cho-

CORREIA, Joel E.; GILBERT, Jeremie; SUBRAMANIAM, Yogeswaran. Strategic litigation impacts: indigenous peoples land rights. New York: Open Society Foundations, 2017. sen by the Xucuru indigenous community to reassure control over their traditional lands. After almost two decades of struggle, the Xucuru people won a central battle for the protection of its traditional land: a recent decision by the Inter-American Court of Human Rights condemned Brazil for a violation of property rights, ordering the immediate and effective delivery of the territory for the community, as well as one million dollars in compensation.

The Inter-American Court has a consolidated jurisprudence regarding indigenous territorial rights, was constructed over seventeen years in a forward-looking perspective and it has been internationally acclaimed and has served as model for several international organizations in matters of indigenous protection ${ }^{2}$.

The Xucuru decision is an important reinforcement of territorial rights, while simultaneously strengthening regional jurisprudence and domestic demands for the implementation of indigenous constitutional rights. However, the decision lacks analysis of some key issues for indigenous peoples. In this scenario, the central problem of the present article is to what extend the decision in the Xucuru case adequately answers the demands of indigenous peoples in Brazil, as well as its adequacy to the indigenous international law framework.

The Xucuru case marks the first decision regarding indigenous rights against Brazil. The country was condemned seven times, in cases related to summary execution (Herzog case), forced labour (Workers of the Farm Brasil Verde case), massacres (Guerrilha do Araguaia and Favela Nova Brasilia cases), forced disappearance (Garibaldi case), mistreatment in a mental institution (Ximene Lopez case) and illegal telephone interceptions (Escher and others case) ${ }^{3}$. So far, Brazil has fully complied with only one case: Escher and others.

The case was under analysis before the Inter-American System for over fifteen years and the decision was

\footnotetext{
2 African Court of Human Rights. African Commission on $\mathrm{Hu}-$ man and Peoples' Right v. Republic of Kenya. Application No. 006/2012 (2017). Judgement May 26 2017; European Court of Human Rights. Case of Sabanchiyeva and others v. Russia. judg. June 06 2013; Human Rights Council, Report of the Special Rapporteur on the rights of indigenous peoples, A/HRC/33/42, Aug. 112016. 3 About the impact of the Inter-American System in Brazil, see: Bernardes, Marcia Nina. Sistema Interamericano de Direitos Humanos como esfera pública transnacional: aspectos jurídicos e políticos da implementação de decisões internacionais. Sur - Revista Internacional de Direitos Humanos, São Paulo, v. 8, n. 15, p. 135-156, 2011.
} 
issued in a critical moment for indigenous peoples in the country, represented by two central fronts of attack. First, a crescent threat of setbacks against the rights of indigenous peoples, simultaneously prolonged by the Legislative $^{4}$ and by the Judiciary ${ }^{5}$, jeopardizing territorial rights guaranteed in the 1988 Constitution. At the same time, violence against indigenous groups has intensified over the last years, with a significant increase in the murders of indigenous members ${ }^{6}$.

In order to analyse the problem, the article is divided into three sections. First, the jurisprudence of the Inter-American Court regarding indigenous territorial rights is summarized, presenting the Court's interpretation of the property right. In sequence, the Xucuru case is described, analysing central points of the final decision.

\footnotetext{
4 Study conducted by the NGO CIMI identified thirty-three ongoing legislative proposals that threatens indigenous rights. From those, seventeen are related to demarcation of territory and thirteen are designated to favor natural resources exploration in traditional lands. The gravest threaten is the PEC 241/00, that alters the Constitution in order to undermine indigenous protection. CONSELHO INDIGENISTA MISSIONÁRIO; CAVALLI, Guilherme (ed.). Congresso Anti-Indigena: os parlamentares que mais atuaram contra os direitos dos povos indígenas. Available at: https://cimi. org.br/wp-content/uploads/2018/09/congresso-anti-indigena.pdf. Access on: 27 Nov. 2018.

5 The most severe restriction imposed by the Judiciary is the temporal frame, imposed by the Supremo Tribunal Federal in reiterated cases, which stipulates that only lands occupied before 1988 receive constitutional protection. BRASIL. Supremo Tribunal Federal. Embargos de Declaração na Petição 3.338-4. Rel. Min. Luís Roberto Barroso, judg. Oct. 23 2013; BRASIL. Supremo Tribunal Federal. 2a Turma. ARE 803.462 -MS. Rel. Min. Teori Zavaski, judg. Dec. 9 2014; BRASIL. Supremo Tribunal Federal. RMS 29.087-MS. Rel. Min. Gilmar Mendes, Sep. 16 2014. In this way, see: SCHWANTES, Susanna; STARCK, Gilberto. Marco temporal e as violações aos direitos dos povos indígenas: análise da constitucionalidade e da convencionalidade a partir da jurisprudência da CIDH. Anuário Brasileiro de Direito Internacional, v. 23, n. 2, p. 148-173, 2018; OSOWSKI, Raquel. O marco temporal para demarcação de terras indígenas, memória e esquecimento. Mediacoes, v. 22, n. 2, p. 320-346, Jul. 2017. Additionally, domestic courts have issued several orders of ownership repossession against indigenous peoples, annulling territorial demarcations.

6 GLOBAL WITNESS. A que custo? Negocios irresponsables y el asesinato de personas defensoras de la tierra y del medio ambiente en 2017, 2018. Available at: https://www.globalwitness.org/ en/campaigns/environmental-activists/defenders-annual-report/. Access on: 27 Nov. 2018. According to the report, Brazil has the biggest rate of murders of defenders of land and environmental rights, which have increased over the last years. The scenario in the country reflects a tendency in the region, as appointed by the UN Special Rapporteur on the Rights of Indigenous Peoples. TAULICORPUS, Victoria. Report of the Special Rapporteur of the Human Rights Council on the rights of indigenous peoples. Sept. 2018. Available at: http://unsr.vtaulicorpuz.org/site/index.php/en/documents/ annual-reports/256-report-ga2018 Access on: 27 Nov. 2018.
}

Lastly, in the third section, the judgement is analysed in a critical manner. It is demonstrated that, in general, it consolidates indigenous international law and reinforces domestic demands for the fulfilment of constitutional rights. However, the decision presents four central deficiencies that may offer inadequate protection to indigenous peoples and, in some cases, represents a setba$\mathrm{ck}$ in the Inter-American protection of territorial land.

The article concludes that the case consolidates indigenous rights to traditional territory at regional and domestic levels, redressing the violation of the right to property. However, the case is a lost opportunity in terms of strategic litigation, as it presents flaws in sensitive points.

\section{Protection of indigenous territorial rights in the Inter-American Court}

The jurisprudence of the Inter-American Court of Human Rights (hereafter, Court) regarding indigenous rights has, for a long time, represented a breakthrough model for the protection of traditional peoples' rights, becoming an institution of inspiration for other human rights' systems and treaties all around the world ${ }^{7}$. The decisions of the Court gave voice to formerly invisible people in the international sphere, thus allowing their demands to be heard ${ }^{8}$. A considerable amount of its decisions were issued even before the adoption of the United Nations Declaration of the Rights of Indigenous Peoples (hereafter, UNDRIP or UN Declaration)

A descriptive analysis of the indigenous jurisprudence issued by the Court can be found in LÓPEZ ESCARCENA, Sebastián. Un derecho jurisprudencial: la propiedad colectiva y la corte interamericana. Revista de derecho, Coquimbo, v. 24, n. 1, p. 133-189, 2017; Mazzuoli, Valério de Oliveira; Ribeiro, Dilton. Indigenous rights before the Inter-American Court of Human Rights: a call for a pro individual interpretation. The Transnational Human Rights Review, v. 2, n. 1, p. 32-62, 2015; RUIZ-CHIRIBOGA, Oswaldo; ROMAN, Gina. Pueblos indígenas y la corte interamericana de Derechos humanos: fondo y reparaciones. In: HAECK, Y.; RUIZ-CHIRIBOGA, O.; BURBANO Herrera, C. (org.). The Inter-American Court of Human Rights: theory and practice, present and future. Cambridge: Intersentia, 2015.

8 RUSSO, Anna Margherita; WENCES, Isabel. De los derechos de los miembros de las comunidades a los derechos de la comunidad y sus miembros: la diversidad cultural y el reconocimiento de la propriedad colectiva de los pueblos indigenas en la Corte Interamericana de Derechos Humanos. In: SANTOLAYA MACHETTI, P.; WENCES, I. (org.). La América de los derechos. Madrid: Centro de Estudios Políticos y Constitucionales, 2016. p. 281-325. p. 296 
in 2007 and foresaw some rights later crystallised in the UN Declaration, such as the right to land demarcation and the right to cultural identity. It is fair to say that the Inter-American jurisprudence is "at the forefront of the progressive development of international indigenous rights" 9

The Court's indigenous jurisprudence is not only remarkable for its forward-looking approach, but also because it is, until now, the human rights body with the most consolidated jurisprudence related to the protection of indigenous territorial rights. Other bodies (such as the Human Rights Committee and the Committee for Eradication of Racial Discrimination) have substantial case law in indigenous rights, but they have only issued final recommendations ${ }^{10}$.

Finally, the Inter-American jurisprudence on indigenous rights has considerable value for the entire human rights system study, as it develops fundamental concepts for the evolution of human rights adjudication, such as the vulnerability assessment, the interdependence among civil and cultural rights, the reach of State duties regarding the protection of rights, interpretation methods, and reach of remedies applied.

Since its creation up until 2018, the Inter-American Court presided over twenty-five contentious cases involving indigenous and tribal peoples. In most of the cases (twelve), the central issue has been territorial protection and land demarcation ${ }^{11}$. The second most common issue has been genocide, massacres and internal conflict (five cases) $)^{12}$. Other issues analysed by the Court include forced disappearance (two cases) ${ }^{13}$, violence against

9 PASQUALUCCI, J. M. The Evolution of International indigenous rights in the Inter-American Human Rights System. Human Rights Law Review, v. 6, n. 2, p. 281-322, 2006. p. 320.

10 ANTKOWIAK, Thomas M. Rights, resources and rhetoric: indigenous peoples and the Inter-American Court. University of Pennsylvania Journal of International Law, Philadelphia, v. 33, n. 1, p. 113-187, 2014. p. 120.

11 Mayagna (Sumo) Awas Tingini vs. Nicaragua, Yakye Axa vs. Paraguay, Sawhoyamaxa vs. Paraguay, Saramaka vs. Suriname, Xámok Kásek vs. Paraguay, Kichwa de Sarayaku vs. Ecuador, Kuna de Madugandí y Emberá de Bayano vs. Panama, Garífuna de Punta Piedra vs. Honduras, Garífuna de la Cruz vs. Honduras and Kaliña y Lokomo vs. Suriname, Xucuru people vs. Brazil.

12 Moiwana vs. Suriname, Río Negro Massacres vs. Guatemala, Operation Genesis vs. Colombia, Miembros de la Aldeia Chicupac y comunidades vecinas del Municipio del Rabinal vs. Guatemala and Massacre Plan de Sanchez vs. Guatemala

13 Tiu Tojín vs. Guatemala, Chitay Nech et all. vs. Guatemala women (two cases) $)^{14}$, political rights (one case) ${ }^{15}$, the criminalization of indigenous leadership (two cases) ${ }^{16}$ and extrajudicial execution (two case) ${ }^{17}$.

The present analysis will focus on territorial rights, considered the most fundamental guarantee for the cultural and physical survival of indigenous peoples, as well as the central right violated in the Xucuru case.

The Court has jurisdiction to rule on violations to the American Convention on Human Rights (hereafter, Convention) or other binding treaties that expressly confer jurisdiction to the Court ${ }^{18}$. As the Convention has no specific rule concerning the collective rights of indigenous peoples, the Court has applied extensive interpretation methods in order to protect the rights of indigenous peoples.

The first one was the interpretation pro homine, or evolutionary, foreseen in Article 29(b) ${ }^{19}$ of the Conven$\operatorname{tion}^{20}$. Another important element was the use of indigenous customary law to specify the right to property, taking into consideration the communitarian tradition regarding the collective ownership of the land ${ }^{21}$. Lastly, the Court referred to a systematic interpretation, based upon the so-called "corpus iuris of the international law of human rights", enshrined in the Vienna Convention, Article 31.2. The Court resorted, therefore, to ILO Convention $169^{22}$, the UNDRIP, reports from the Special Rapporteur on the rights of indigenous peoples,

\footnotetext{
14 Fernandez Ortega y otros vs. Mexico and Rosendo Cantu y otra vs. Mexico

15 Yatama vs. Nicaragua

16 Norín Catrimán y otros vs. Chile and López Alvarez vs. Honduras

17 Aloeboetoe vs. Surinam and Escué Zapata vs. Colombia

18 The Court has already recognized its jurisdiction to rule about
} the following treaties: Inter-American Convention on Forced Disappearance of Persons and the Protocol to the American Convention on Human Rights in the Area of Economic, Social and Cultural Rights in matters regarding unions and education; Inter-American Convention to Prevent and Punish Torture and Inter-American Convention on the Prevention, Punishment and Eradication of Violence Against Women,

19 ACHR, "Art. 29. No provision of this Convention shall be interpreted as: $[\ldots]$ b. restricting the enjoyment or exercise of any right or freedom recognized by virtue of the laws of any State Party or by virtue of another convention to which one of the said states is a party"

20 IACtHR. Case of the Mayagna (Sumo) Awas Tingni Community v. Nicaragua. Preliminary Objections. February 1, 2000, \$\$146-149.

21 IACtHR. Case of the Mayagna (Sumo) Awas Tingni Community v. Nicaragua. Preliminary Objections. February 1, 2000, \$149

22 The Convention is the only binding instrument regarding indigenous peoples rights in the international sphere. 
reports from several UN Committees and multiple domestic legislation and jurisprudence from Latin America countries ${ }^{23}$.

The protection of the indissoluble bond between indigenous communities and their territories was performed under the right to property (Article 21) ${ }^{24}$, combined with the rights to cultural identity, non-discrimination and self-determination. It imposed to States duties to delimitate, demarcate and title traditional territory, as well as to abstain from any act that could harm total use and enjoyment of the property ${ }^{25}$. In recent cases, the Court has ruled about the obligation to perform a saneamiento ${ }^{26}$ of the lands, a process entrusted to the State to remove any interference in the territory, enabling total use and enjoyment of the lands ${ }^{27}$.

The Court affirmed that the protection of traditional communal property must ensure control and use of natural resources, which are fundamental for their economic, social and cultural survival. The Court established three safeguards that specifically focused on concessions for exploration of natural resources in indigenous and tribal lands: free, prior and informed consultation, benefit sharing and prior environmental and social impact assessment, accordingly with international parameters of excellence ${ }^{28}$. In addition to the procedural safeguards, the Court stated that exploration of natural resources might not endanger the cultural and physical survival of the community, as the safeguards "are intended to preserve, protect and guarantee the special relationship that the members of the $[\ldots]$ com-

23 IACtHR. Case of the Yakye Axa Indigenous Community v. Paraguay. Merits, Reparations and Costs. June 17, 2005, \$\$123-131; IACtHR. Case of Garífuna Punta Piedra Community and its members v. Honduras. Preliminary Objections, Merits, Reparations and Costs. October 8, 2015. Series C No. 304, \$\$174-179.

24 ACHR, "Article 21. Right to Property. 1. Everyone has the right to the use and enjoyment of his property. The law may subordinate such use and enjoyment to the interest of society."

25 IACtHR. Case of the Mayagna (Sumo) Awas Tingni Community v. Nicaragua. Preliminary Objections. February 1, 2000. Series C No. 66, \$153.

26 The Spanish word "saneamiento" could not be translated to English without loss of its meaning, so it was decided to use it in Spanish. "Saneamiento" is a juridical institute in civil law that means the obligation of final delivery of a property, free from any interference or disturbance.

27 IACtHR. Case of Garífuna Punta Piedra Community and its members v. Honduras. Preliminary Objections, Merits, Reparations and Costs. October 8, 2015, $\$ 181$

28 IACtHR. Case of the Saramaka People. v. Suriname. Preliminary Objections, Merits, Reparations, and Costs. November 28, 2007, s\$129-140. munity have with their territory". ${ }^{29}$

The most innovative safeguard proposed by the Court is the right to consultation. Consultation should be carried on "in good faith, through culturally appropriate procedures and with the objective of reaching an agreement" ${ }^{30}$; it must take place prior to harmful activities and the community needs to be well-informed about possible risks and impacts ${ }^{31}$ and must achieve consent in cases regarding "large-scale development or investment projects that would have a major impact within Saramaka territory"32. The formal elements of the consultation, especially regarding who should be consulted, should be defined by the community, according to its practice. ${ }^{33}$

The right to communal property over traditional territory is the central threshold of the indigenous territorial jurisprudence, but it is reinforced by the recognition of other rights. Indigenous peoples must also have access to effective procedures for protection, guarantee and promotion of their rights over the territory, according to the Convention, arts. 8 (right to a fair trial) and 25 (right to juridical protection) ${ }^{34}$. Considering the inseparable relationship between indigenous territory and cultural and physical survival of the people, in cases in which the communities are living outside the territory, the State has the duty to provide minimum conditions for a life with dignity, including housing, water, food security and sanitation, configuring a right to vida digna ${ }^{35}$

29 IACtHR. Case of the Saramaka People v. Suriname. Interpretation of the Judgment on Preliminary Objections, Merits, Reparations and Costs. August 12, 2008, §36

30 IACtHR. Case of the Saramaka People. v. Suriname. Preliminary Objections, Merits, Reparations, and Costs. November 28, 2007, $\$ 131$.

31 IACtHR. Case of the Saramaka People. v. Suriname. Preliminary Objections, Merits, Reparations, and Costs. November 28, 2007, $\$ 131$.

32 IACtHR. Case of the Saramaka People. v. Suriname. Preliminary Objections, Merits, Reparations, and Costs. November 28, 2007, $\$ 134$

33 IACtHR. Case of the Saramaka People v. Suriname. Interpretation of the Judgment on Preliminary Objections, Merits, Reparations and Costs. August 12, 2008., \$\$16-18.

34 IACtHR. Case of the Mayagna (Sumo) Awas Tingni Community v. Nicaragua. Preliminary Objections. February 1, 2000, \$63; IACtHR. Case of Kichwa Indigenous People of Sarayaku v. Ecuador. Merits and reparations. June 27, 2012, \$263; IACtHR. Case of Garífuna Punta Piedra Community and its members v. Honduras. Preliminary Objections, Merits, Reparations and Costs. October 8, 2015, §251

35 IACtHR. Case of the Yakye Axa Indigenous Community v. Paraguay. Merits, Reparations and Costs. June 17, 2005, §162; IACtHR. 
(Article 4). A right that is implicit in the Convention and mentioned by the Court in indigenous cases is the right to cultural identity, which is considered to be "an ingredient and a crosscutting means of interpretation to understand, respect and guarantee the enjoyment and exercise of the human rights of indigenous peoples and communities protected by the Convention" ${ }^{36}$.

\section{The Court's final decision in the Xucuru Case}

Brazil has accepted the jurisdiction of the Court in December 1998. The plaintiffs submitted a petition to the Commission in October 2002, through its representatives, which included the NGOs Movimento Nacional de Direitos Humanos/Regional Nordeste, Gabinete de Assesoria Jurídica de Organizaçõs Populares (GAJOP) and Conselho Indigenista Misionário (CIMI) ${ }^{37}$.

The Commission only issued the admissibility report after seven years, in October 2009, and the merit report six years later, in July 2015. As the State did not accept the recommendations proposed, the Commission filed a demand to the Court in March 2016. After a public hearing carried out in January 2017, the Court issued a final decision in February 2018.

The delay for a final decision in the Commission is noteworthy. It lasted fourteen years between the representatives' petition and the demand to the Court, and sixteen years until a final decision by the Court. The average time for a decision in indigenous jurisprudence, from the petition in the Commission until the final decision of the Court, is almost ten years (111.6 months) and, in general cases, it is almost nine years (106 months). The biggest struggle of time is during the Commission's procedure, as the duration before the Court is close to the average length of time (almost two years).

Case of the Sawhoyamaxa Indigenous Community v. Paraguay. Merits, Reparations and Costs. March 29, 2006, \$\$163-164; IACtHR. IACtHR. Case of the Xákmok Kásek Indigenous Community. v. Paraguay. Merits, Reparations and Costs. August 24, 2010.

36 IACtHR. Case of Kichwa Indigenous People of Sarayaku v. Ecuador. Merits and reparations. June 27, 2012, \$213

37 All cases presented against Brazil and decided by the Court were initiated by petition from a Human Rights NGO, demonstrating a central role of these organizations for the country. The preponderance of NGO is also present in territorial indigenous cases before the Court, as the victims were always represented by a NGO, sometimes in parallel with natural persons.
The problems regarding an excessive lapse of time for a final judgement in the Inter-American System are well-known and solutions have been proposed and applied $^{38,}$ even though it is still a matter of concern. The Xucuru case is the longest one among indigenous territorial decisions before the Court and it is hard to find elements to justify such delay. The case did not involve additional complexity compared to other indigenous cases, nor did it demand additional means of proof.

In the present case, the lack of legal certainty over the territory continuously exposed the community to violence. While the case was under analysis by the System, the community suffered the attempt murder of its leader, as well as a series of threats, demonstrating the gravity of the long duration of the trial. The unreasonable length of time for judgment on human rights' violations can configure itself as a violation of guarantees, as has already been ruled by the Court ${ }^{39}$.

The procedures before the Court took 23 months. The victims were represented by two national NGOs (GAJOP and CIMI, which were already participants in the procedures before the Commission) and one international NGO (Justiça Global). The representatives did not present initial considerations, nor did they propose evidence and a list of witnesses.

In order to prove the allegations, the Court based itself upon documents presented by the parties, written testimonials from expert witnesses and testimonials produced in the public hearing from a witness and an expert witness.

Contrary to former indigenous cases, the Court did not perform on-site procedures. Visits to the community were carried out in all indigenous territorial cases since Kichwa de Sarayaku, including Garífuna de Punta Piedra, Garífuna Triunfo de la Cruz and Kaliña y Lokono. The visits were considered essential for clarification of the facts, mainly when involving third parties and

\footnotetext{
38 SANCHEZ, Nelson Camilo; CÉRON, Laura Lyons. El elefante en la sala: el retraso procesal en el sistema de peticiones individuales del sistema interamericano. In: DEJUSTICIA. Desafíos del sistema interamericano de derechos humanos: nuevos tiempos, viejos retos. Bogotá, D.C.: Dejusticia, 2015. p. 230-275.

39 IACtHR. Case of the Afro-descendant Communities displaced from the Cacarica River Basin (Operation Genesis) v. Colombia. Preliminary Objections, Merits, Reparations and Costs. November 20, 2013, \$127; IACtHR. Case of the Xákmok Kásek Indigenous Community. v. Paraguay. Merits, Reparations and Costs. August 24, 2010, \\$132-138.
} 
for the stimulation of dialogue in a victim-centred perspective ${ }^{40}$. The present case involved a complex situation of conflict with third parties and an on-site procedure could have assisted the Court with fact-finding and clarifying uncertainties.

\subsection{Factual background}

In Brazil, the protection of indigenous territory is constitutionally guaranteed. According to Article 231 of the 1988 Brazilian Constitution, the State has the duty to demarcate and protect traditional territory, which includes all lands indispensable for indigenous physical and cultural reproduction, as well as the ones used for productive activities and the natural resources indispensable for their well-being. The demarcation is a technical procedure commissioned to the National Foundation of the Indigenous (FUNAI). Even though the Constitution established a five-year period for the demarcation of all indigenous lands, only $67 \%$ of indigenous lands in 2018 were demarcated ${ }^{41}$ and conflicts with non-indigenous occupation/exploration persist even in homologate indigenous lands.

The demarcation of the Xucuru traditional territory started in 1987 and involved a series of administrative procedures and judicial actions contesting the demarcation of the land. The homologation of the traditional land's demarcation occurred in April 2001 and it was finally titled in November 2005. However, until 2018, the land had not been totally restored and delivered to the community, as six non-indigenous persons still occupied the territory ${ }^{42}$. Some judicial actions challenging the demarcation were still continuing during the decision of the Court, generating a situation of legal uncertainty ${ }^{43}$.

\footnotetext{
40 IACtHR. Case of the Community Garifuna Triunfo de la Cruz and its members v. Honduras. Merits, Reparations and Costs. October 8, 2015. Voto concurrente del Juez Humberto Antonio Sierra Porto, $\int 11-19$.

${ }^{41}$ INSTITUTO SOCIOAMBIENTAL. Situação das terras indígenas no Brasil. Available at: https://pib.socioambiental.org/pt/ Situa $\%$ C3\%A7\%C3\%A3o_jur\%C3\%ADdica_das_TIs_no_Brasil_ hoje. Access on: 12 Dec. 2018.

42 In the final allegations brief, the representatives stressed that the regain of the territory and expulsion of non-indigenous occupants between 2000 and 2018 only occurred regarding mobilization and resistance from the indigenous community, and not on account of State conduct.

43 IACtHR. Case of the Xucuru Indigenous People and its members v. Brazil. Preliminary Objections, Merits, Reparations and
}

The process involved acts of violence. The Court stated that "the process of delimitation, demarcation and final delivery of the indigenous land of Xucuru People was marked by a context of insecurity and threats, resulting in the death of several indigenous leaders" ${ }^{44}$. In May 1998, the leader of the community, Cacique Xicão, was murdered by order of a local farmer. His son, Cacique Marquinhos, survived an attempted murder in 2003, but two indigenous individuals who had accompanied him died ${ }^{45}$. Additionally, the victims mentioned in the final allegations regarding the death of another indigenous leader, Chico Quelé, in 2001, were allegedly related to a land-based conflict. They also denounced a scenario of criminalization of the indigenous members by the government, with several criminal procedures open against them.

\subsection{Preliminary exceptions}

Brazil alleged four preliminary exceptions against the Commission's demand and the Court denied all of them. First, it alleged that the publication of a preliminary report by the Commission on its website violated the Convention. The Court dismissed the allegation, affirming that the State did not present enough arguments for the violation and referred to two former cases against Brazil: Favela Nova Brasília and Workers of Brasil Verde Farm.

The State also alleged a lack of jurisdiction ratione temporis regarding the signature of the Convention and the acceptance of the Court's jurisdiction. The Court reiterated its jurisdiction to consider only facts occurred after December $1998^{46}$. It is interesting to note that,

Costs. February 5, 2017, \$\$71-91. In the public hearing, judge Pazmiño Freire questioned about the exact number of people occupying illegally the territory. The expert witness Sr. José Sérgio de Souza could not answer exactly (he said there were six families, not specifying the number of people) and neither the final allegations nor the decision mentions the exact number of occupants and the total area occupied. AUDIENCIA Pública. Caso Pueblo Indígena Xucuru y sus miembros Vs. Brasil. Parte 2. Realização de Corteidh. Guatemala City: Corteidh, 2017. (86 min.). Available at: https:// vimeo.com/album/4489982/video/209458762. Access in: 2 Dec. 2018. From min. 40.

${ }^{44}$ IACtHR. Case of the Xucuru Indigenous People and its members v. Brazil. Preliminary Objections, Merits, Reparations and Costs. February 5, 2017, §87.

45 IACtHR. Case of the Xucuru Indigenous People and its members v. Brazil. Preliminary Objections, Merits, Reparations and Costs. February 5, 2017, \$S76 and 87-91.

46 IACtHR. Case of the Moiwana Community v. Suriname. Pre- 
contrary to prior indigenous cases, the Court did not refer to the continuous effects of indigenous land dispossession $^{47}$, even though this argument was extensively alleged by the representatives in their final allegations brief, referring to broad Court jurisprudence.

Additionally, the State alleged a lack of jurisdiction ratione materiae regarding the violation of ILO Convention 169. The Court responded that it only has jurisdiction to rule on violations of the Convention, but other treaties, such as the ILO Convention, can be used to interpret the content and reach of the rights enshrined in the Convention.

Finally, the State alleged an absence of exhaustion of internal resources. The Court dismissed the allegation, affirming that the appropriate time for this argument would be before the Commission, prior to the admissibility report.

\subsection{Violation of the right to property - art. 21}

After stating proven facts and dismissing preliminary objections, the Court moved on to the analysis of violated rights. The central matter of the case was the violation of the right to property, caused, simultaneously, by the persistence of non-indigenous occupants in the traditional territory, and by the unreasonable lack of time until final delivery of the property. The argumentation of the Court regarding collective property rights over traditional territory reiterates its previous jurisprudence in the matter, referring to its consolidated jurisprudence on indigenous territorial rights (see topic 2, supra).

The Court reiterated that the right to property foreseen in Article 21 protects the relationship between indigenous peoples and their lands, considering the customary communal use of traditional lands. The protection of traditional territory was also considered essential for the protection of the right to cultural identity and the survival of the community and its members. Applying the interpretation rule contained in Article 29.b, the Court analysed Article 21 with support from the so-called corpus iuris, composed by ILO Convention

liminary Objections, Merits, Reparations and Costs. June 15, 2005. Series C No. 124, \$\$37-44.

47 IACtHR. Case of the Moiwana Community v. Suriname. Preliminary Objections, Merits, Reparations and Costs. June 15, 2005, $\iint 37-44$.
169, UNDRIP, domestic law and other international instruments and decisions.

The Court briefly summarized all former indigenous territorial decisions, presenting the State obligations regarding traditional territory, especially the obligation to guarantee effective control of the territory (including its natural resources) by the indigenous without third party interference. The right to control the territory is a consequence of the right to self-determination, and yet the Court did not refer to this right ${ }^{48}$.

After having established the right to collective property of the territory, the Court followed up with an analysis of the principle of legal certainty and the obligation to respect rights $\left(\right.$ Art. $\left.1^{\circ}\right)$. The Court stated, "Legal certainty is assured - among other conceptions - as long as there is trust that rights and freedoms fundamental will be guaranteed and respected to all persons under a State jurisdiction" ${ }^{49}$.

Citing the testimonial from the UN Special Rapporteur for the Rights of Indigenous Peoples, the Court declared that legal certainty for indigenous peoples means no external interference in the traditional territory. The right to collective property is dependent on the saneamiento of the territory, meaning, the removal of any kind of external interference. In the words of the Court, "if that is not assured, for the Court it is clear that the right to collective property was not assured completely. Therefore, the Court asserts that the administrative procedures of delimitation, demarcation, entitlement and saneamiento of indigenous territory are mechanisms that assure legal certainty and protection to this right" ${ }^{50}$.

48 IACtHR. Case of the Xucuru Indigenous People and its members v. Brazil. Preliminary Objections, Merits, Reparations and Costs. February 5, 2017, \$\$115-120.

49 IACtHR. Case of the Xucuru Indigenous People and its members v. Brazil. Preliminary Objections, Merits, Reparations and Costs. February 5, 2017, \$123. Original in Spanish: "la seguridad jurídica se ve asegurada -entre otras concepciones- en tanto exista confianza que los derechos y libertades fundamentales serán respetados y garantizados a todas las personas bajo la jurisdicción de un Estado parte de la Convención Americana." Translated by the author.

50 IACtHR. Case of the Xucuru Indigenous People and its members v. Brazil. Preliminary Objections, Merits, Reparations and Costs. February 5, 2017, \$124. Original in Spanish: "Si lo anterior no se verifica, para la Corte es claro que el derecho de propiedad colectiva no ha sido garantizado por completo. Así, la Corte estima que los procesos administrativos de delimitación, demarcación, titulación y saneamiento de territorios indígenas son mecanismos que garantizan seguridad jurídica y protección a este derecho.” Translated by the author. 
The Court distinguished the duty of saneamiento from a possible conflict with private owners. The duty of $s a$ neamiento emerges when the property rights have ever been ensured, while in a conflict with a private owner, the conflict must be resolved case by case considering the elements: legality, necessity, and proportionality, as well as its legitimate objective in a democratic society and in the absence of threats to the survival of indigenous peoples. The Court asserted that the Xucuru case is a matter of saneamiento and, therefore, the reference to the ponderation between private property and traditional territory is inappropriate ${ }^{51}$.

\subsection{Violation of the right to a fair trial and judicial guarantees - arts. 8.1 and 25}

Parallel to the substantive right to property, indigenous peoples have the procedural right to access effective procedures for protection, guarantee and promotion of their rights over the territory, according to the Convention, arts. $8^{52}$ and $25^{53}$. Such procedures must be adequate to indigenous particularities, as well as to their situation of vulnerability and to their customary law. The State obligation comprises not only a legal existence of these procedures, but also their effectivity to guarantee indigenous rights, including a reasonable duration of procedures ${ }^{54}$.

In the case under analysis, the central aspect subject to evaluation was an alleged violation of reasonable time. For this analysis, the Court established four elements: complexity of the theme, conduct of involved parties (State and citizens) and effects generated by the

\footnotetext{
51 IACtHR. Case of the Xucuru Indigenous People and its members v. Brazil. Preliminary Objections, Merits, Reparations and Costs. February 5, 2017, §125-127.

52 ACHR, "Article 8. Right to a Fair Trial. 1. Every person has the right to a hearing, with due guarantees and within a reasonable time, by a competent, independent, and impartial tribunal, previously established by law, in the substantiation of any accusation of a criminal nature made against him or for the determination of his rights and obligations of a civil, labor, fiscal, or any other nature."

53 ACHR, "Article 25. Right to Judicial Protection. 1. Everyone has the right to simple and prompt recourse, or any other effective recourse, to a competent court or tribunal for protection against acts that violate his fundamental rights recognized by the constitution or laws of the state concerned or by this Convention, even though such violation may have been committed by persons acting in the course of their official duties."

54 IACtHR. Case of the Xucuru Indigenous People and its members v. Brazil. Preliminary Objections, Merits, Reparations and Costs. February 5, 2017, \§130-134
}

procedure.

Generally, the Court recognized that indigenous cases might justify a delay of several years, considering the immanent complexity of the cases. The Xucuru case represented a complex case, as it involved a gross amount of non-indigenous occupants. However, the Court considered that it did not justify a delay of twenty-eight years (nineteen of them under the jurisdiction of the Court) to conclude the procedures; the procedural delay was directly attributed to the State's conduct, and, therefore, the lapse of time until the saneamiento was excessive and violated arts. 8.1 and 1.1 of the Convention ${ }^{55}$.

The State also took an unreasonable amount of time to judge judicial actions against the demarcation of indigenous territory, generating a lack of legal certainty and violating articles 25, 21 and 1.1 of the Convention ${ }^{56}$.

Considering the duty to adapt domestic legislation according to the Convention (Art.2), the representatives had alleged that Brazilian legislation lacked prevision of an effective instrument, as it did not establish final terms for the procedures and, therefore, violated Article 2. However, the Court alleged the absence of elements to determine which rule was in conflict with the Convention, as well as it was not clear not how this conflict would have negatively affected the protection of Xucuru territory. Consequently, the Court did not recognize the responsibility of the State for the violation of Article $2^{57}$.

\subsection{Reparation measures}

After having recognized the violation of rights, the Court established appropriate measures to remedy the suffered damage and to avoid future violations (Art. $\left.63.1^{58}\right)$. In the Xucuru case, the Court was considerably

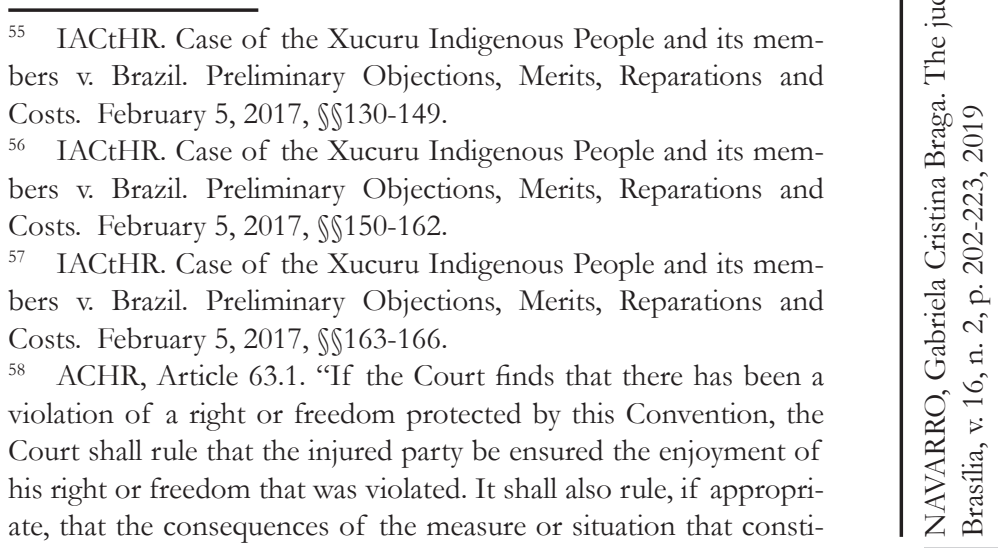


narrow in the application of the reparation measures, both in the number of measures and in their extent.

First, the Court applied a restitution measure, the final delivery of the traditional territory to the community, immediately and effectively. The Court also stated that the territory should be free from any intrusion or interference, caused by the State or by a third party, which harmed or threatened the value, use or enjoyment of the territory. However, regarding the existence of private property within the territory, the Court stated the obligation to buy or expropriate it or, if not possible, offer alternative lands to the Xucuru with their consent $^{59}$.

There is a contradiction between this reparation measure and the Court's merit analysis. In the merit analysis, the Court differentiated conflict between private property and traditional territory (solved by case analysis according to proportionality criteria) from the duty to perform saneamiento (solved by the removal of any interference to an already registered property), framing the present case in the second situation. However, the flexibility granted to the State regarding final delivery of the territory collides with the duty of saneamiento, as it questions the validity of the property registration itself.

In other words, if the Court stipulates the State obligation to buy or expropriate private property, it assumes that the property title of the traditional territory is not definitive and thus subject to restrictions. Even more, the possibility to offer alternative lands instead of removing non-indigenous occupants from the territory mitigates the saneamiento duty in a manner contrary to the one discussed in the merit analysis.

Secondly, the Court issued a satisfaction measure, i.e. the publication of the judgment. While the full content of the judgment should be available on the State's website, the abstract of the decision should be published in the official gazette. The term for the conclusion of the measures is six months. There is no specification regarding the language of the publications. Both publications have been made by the government. The decision is available in Portuguese on the website of the Ministry of Foreign

tuted the breach of such right or freedom be remedied and that fair compensation be paid to the injured party."

59 IACtHR. Case of the Xucuru Indigenous People and its members v. Brazil. Preliminary Objections, Merits, Reparations and Costs. February 5, 2017, §193.
Affairs $^{60}$ and the abstract of the decision was published in the official gazette on September 13, $2018^{61}$.

Lastly, the Court ruled on compensation measures. As the parties had not alleged material damage, the Court considered only immaterial damage as a result of the violations. The Court ordered the creation of a communitarian development fund in the amount of one million dollars. The State had 18 months to establish the fund, which was to be created and administrated with the direct consultation of the community. The Court did not stipulate any special measure regarding the management of the fund or its destination. Regarding the costs of the cause, the Court stipulated a compensation in the amount of ten thousand dollars.

\section{Absences in the decision}

The decision in the Xucuru case consolidates the Court's jurisprudence regarding territorial rights, reaffirming the protection under Article 21 and stressing the obligations generated to the State, mainly the duty to perform saneamiento. It also addresses the historical violation of human rights against the Xucuru community, offering the opportunity to redress their suffering. From these perspectives, it is a very important decision and should therefore be acknowledged for enhancing the protection of indigenous communities.

However, the decision is not free from criticism. It is the intention of this paper to point out some elements that are absent in the decision and that could have offered a better protection of human rights. The analysis focuses on four points: the right to personal integrity and protection of leadership, reference to the American Declaration on the Rights of Indigenous Peoples (hereafter, ADRIP), the reach of applied reparation measures and the identification of injured parties. The low repercussion of the decision in the domestic sphere is also pointed out as an external absence.

60 BRASIL. Palácio do Itamaraty. Sentença da Corte Interamericana de direitos humanos no caso trabalhadores da fazenda Brasil Verde. Available at: http://www.itamaraty.gov.br/pt-BR/direitos-humanos-e-temassociais/sentenca-corte-interamericana-de-direitos-humanos-nocaso-trabalhadores-da-fazenda-brasil-verde. Access on: 3 Dec. 2018. 61 BRASIL. Ministério dos Direitos Humanos. Portaria n. 301 de 06 de setembro de 2018. Available at: http://pesquisa.in.gov.br/ imprensa/jsp/visualiza/index.jsp?jornal $=515 \&$ pagina $=107 \& \mathrm{da}$ ta $=13 / 09 / 2018$. Access on: 3 Dec. 2018. 


\subsection{Personal integrity and protection of leadership}

The representatives and the Commission alleged that the lack of protection of the territory generated a continuous situation of insecurity and violence within the territory, violating the moral and physical integrity of the community's members, and, therefore, violating Article $5.1^{62}$ of the Convention. However, the Court considered that the facts related were presented extemporaneously and could not be considered, even though it recognized a general situation of violence and conflict ${ }^{63}$.

In the application presented to the Court, the Commission refers very briefly to a violation of Article 5.1 and it does not specify the acts of violence related to the case. In the final merit report, the Commission had presented a wider justification for the recognition of the violation and it had discriminated acts of violence in the community (murders and threats). The Commission stated:

\begin{abstract}
The Commission must observe that one of the consequences of the lack of appropriate recognition and lack of effective protection and non-intrusion in the ancestrally occupied territory by the indigenous people Xucuru generated a situation of insecurity and violence, as it was proved. In other words, this situation resulted in the Xucuru indigenous people not being able to enjoy or live peacefully in their territory; on the contrary, they have lived in a situation of precariousness, conflict and even risk to life and personal integrity of their members. By virtue of the principle iura novit curia, the Commission considers that the effects of state acts and omissions on the collective property of the Xucuru people have further provoked a violation of the psychological and moral integrity of its members, in violation of Article 5.1 of the American Convention. ${ }^{64}$
\end{abstract}

62 ACHR, "Article 5. Right to Humane Treatment. 1. Every person has the right to have his physical, mental, and moral integrity respected."

${ }_{63}$ IACtHR. Case of the Xucuru Indigenous People and its members v. Brazil. Preliminary Objections, Merits, Reparations and Costs. February 5, 2017, \$\$171-181.

${ }^{64}$ IACHR. Informe n. 44/15. Caso 12.728, Informe de Fondo Povo Indigena Xucuru Brasil. July 28 2015, §85. Original in Portuguese: "A Comissão deve observar que uma das consequências da falta de reconhecimento oportuno e da falta de proteção eficaz e desintrusão do território ocupado historicamente pelo povo indígena Xucuru gerou uma situação de insegurança e violência, como foi dado por provado. Em outras palavras, esta situação resultou em que o povo indígena Xucuru não pudesse desfrutar nem viver pacificamente em seu territ6rio, senão pelo contrário, haja vivido numa situação de precariedade, conflito e até mesmo risco para a vida e
In the final allegations brief, the Commission did not make any observation regarding the situation of violence, neither did it approach the violation of Article 5.1.

The representatives did not present brief of pleadings, motions and evidence. However, in the brief of final allegations, they extensively presented the violence experienced by the community, comprehensively listing the facts related to threats, murders, attacks and criminalization of indigenous members. Several former decisions of the Court were mentioned in which the Court stressed that emotional distress caused by dreadful conditions generates state responsibility.

In response to the demands, the Court first stated general terms of protection. It affirmed that analysis of the violation of Article 5.1 must be executed by case analysis, considering the specificities of the victims. States have a duty not only to abstain from any act that could harm personal integrity, but also from protecting the victims against third party acts. The State's obligation to protect hangs upon knowledge of a real and immediate risk to an individual or a determinate group of individuals, as well as the reasonable possibility to avoid the risks. The Court also reiterated that States should pay special attention to persons in situations of vulnerability, as it is the situation of indigenous leadership and indigenous members acting in defence of the territory and human rights. In the words of the Court,

The Court reiterates that the defence of human rights can only be freely executed when the persons that execute it are not victims of threats of any kind or physical, mental or moral aggression or any other hostile act. For such result, the State must not only create legal and formal conditions, but also guarantee factual circumstances in which human rights defenders can freely develop their function. [...] In definitive terms, the State's duty to guarantee the rights to life and personal integrity is reinforced when referring to human rights defenders. ${ }^{65}$

integridade pessoal de seus membros. Em virtude do principia iura novit curia, a Comissão considera que os efeitos das ações e omissões estatais relativas it propriedade coletiva do povo Xucuru provocou adicionalmente uma violação a integridade psíquica e moral de seus membros, em violação ao artigo 5.1 da Convenção Americana. " Translated by the author.

65 IACtHR. Case of the Xucuru Indigenous People and its members v. Brazil. Preliminary Objections, Merits, Reparations and Costs. February 5, 2017, \$175. Original in Spanish: “175. La Corte reitera que la defensa de los derechos humanos sólo puede ejercerse libremente cuando las personas que la realizan no son víctimas de amenazas ni de cualquier tipo de agresiones físicas, psíquicas o morales u otros actos de hostigamiento183. Para tales efectos, es deber del Estado no sólo crear las condiciones legales y formales, sino también 
The Court's statement has particular importance, as it was the first time the Court used the expression "human rights defenders" on its case law regarding indigenous rights ${ }^{66}$, representing sensitivity to the current situation of increasing violence against human rights defenders, in general, and indigenous leadership, in particular.

However, the Court dismissed the violation of Art. 5.1 in the present case, affirming that "the Commission did not comply with the burden of the proof considering that it did not present the juridical and factual argumentation necessary, it did not indicate the concrete facts that configured the alleged violation, nor their perpetrators." ${ }^{67}$ The Court recognized that the representatives of the victims presented specific elements, but only in public hearings and in final allegations, that is to say, extemporaneously. The Court could not analyse such facts, considering the State's right to defence.

In conclusion, even though the Court recognized a situation of tension and violence, as well as a general duty to protect human rights defenders, the Commission's argumentation did not offer sufficient basis and the representative's arguments were presented extemporaneously. The Court determined that it was not possible to conclude that the State violated Art. 5.1, personal integrity ${ }^{68}$.

There is a similarity between this case and two recent decisions against the State of Honduras ${ }^{69}$, Garifuna de

garantizar las condiciones fácticas en las cuales los defensores de derechos humanos puedan desarrollar libremente su función. [...] En definitiva, la obligación del Estado de garantizar los derechos a la vida e integridad personal de las personas se ve reforzada cuando se trata de un defensor o defensora de derechos humanos." Footnotes omitted. Translated by the author.

66 The Court has already ruled specifically about the murder of human rights defenders in two paradigmatic decision. IACtHR. Case of Kawas Fernández v. Honduras. Merits, Reparations and Costs. April 3, 2009; IACtHR. Case of Human Rights Defender et al. v. Guatemala. Preliminary Objections, Merits, Reparations and Costs. August 28, 2014.

${ }_{67}$ IACtHR. Case of the Xucuru Indigenous People and its members v. Brazil. Preliminary Objections, Merits, Reparations and Costs. February 5, 2017, \$178. Original in Spanish: "la Comisión no cumplió con la carga de probar su alegato teniendo en cuenta que no presentó la argumentación jurídica y fáctica necesaria; no indicó los hechos concretos que configurarían la alegada violación, ni los responsables de la misma." Translated by the author.

${ }_{68}$ IACtHR. Case of the Xucuru Indigenous People and its members v. Brazil. Preliminary Objections, Merits, Reparations and Costs. February 5, 2017, SS171-181.

69 Just like Brazil, Honduras is one of the most violent countries for the defense of natural resources and land. GLOBAL WITNESS.
Punta Piedra and Garifuna Triunfo de la Cruz. In both of them, indigenous communities alleged a general situation of violence caused by a lack of saneamiento of traditional territories and stated that the murders of indigenous leadership were a violation of the right to life. The Court dismissed both demands, alleging insufficient evidence to determine knowledge by the State about the imminent risk ${ }^{70}$. The cases are different, as the demands in the Garifunas' cases regarded a violation of the right to life, while the demands in Xucuru case referred to the right to personal integrity. The dismissal argument is also different, but the three cases analysed in parallel might demonstrate, simultaneously, an increasing demand for the protection of indigenous leadership and the inadequacy of the Court's instruments to deal with the leadership's protection in contentious cases ${ }^{71}$.

The protection of leadership against attacks during the procedures and after the decision is a matter that might demand further development from the Court in future cases. It should be aware of the social context of Latin America and the escalation of murders and threats against human right defenders ${ }^{72}$. The Court mi-

A que custo? Negocios irresponsables y el asesinato de personas defensoras de la tierra y del medio ambiente en 2017, 2018. Available at: https://www.globalwitness.org/en/campaigns/environmentalactivists/defenders-annual-report/. Access on: 27 Nov. 2018.

70 IACtHR. Case of the Community Garifuna Triunfo de la Cruz and its members v. Honduras. Merits, Reparations and Costs. October 8, 2015, \$\$201-214; IACtHR. Case of Garífuna Punta Piedra Community and its members v. Honduras. Preliminary Objections, Merits, Reparations and Costs. October 8, 2015, J\$257-280.

71 The Court has approached the demands for protection of indigenous leaderships in a case-by-case analysis, demanding strong evidences to declare violations. The Inter-American Commission has demonstrated a deep concern with the thematic, as it adopted in February 2018 the "Report on Comprehensive Protection Policies for Human Rights Defenders", in order to provide States with parameters for the adoption of policies in the domestic level regarding the protection of human rights defenders. Also, the Commission has presented several press releases demonstrating concern with the position of human right defenders. CIDH. Hacia una política integral de protección a personas defensoras de derechos humanos. OEA/Ser.L/V/II. Doc. 207/17 29 diciembre 2017. CIDH. CIDH condena asesinatos a defensoras y defensores de derechos humanos en la región. 7 de febrero de 2017. http://www.oas.org/es/cidh/ prensa/comunicados/2017/011.asp; CIDH. CIDH condena assassinato de defensores de direitos humanos no Brasil. 27 de abril de 2016. http://www.oas.org/pt/cidh/prensa/notas/2016/054.asp. $\mathrm{CIDH}$. CIDH condena os assassinatos de defensores de direitos humanos vinculados ao direito ao meio ambiente, terra e trabalhadores rurais no Brasil.27 de julho de 2018. http://www.oas.org/pt/cidh/ prensa/notas/2018/168.asp

72 TAULI-CORPUS, Victoria. Report of the Special Rapporteur of the Human Rights Council on the rights of indigenous peoples. Sept. 2018. Available at: http://unsr.vtaulicorpuz.org/site/index.php/en/docu- 
ght also consider that conflict remains even after the delivery of the final decision and may be even intensified, considering the length of time to implementation ${ }^{73}$, justifying the application of special measures to protect human rights defenders.

It is essential to bear in mind that violation of article 5.1 is directly related to the violation of Article 21, as the lack of final delivery of the property generates conflicts and violence that hazards the life of indigenous leaders. Therefore, the Court could have used a systematic interpretation, expanding the State's obligation under Article 21 to the protection of indigenous leaders. The measure could attenuate the burden of proof and increment the indigenous protection.

To recognize the international responsibility of States for the lack of protection of human rights defenders is a possible answer, but it may also prove complicated as it involves a hard burden of proof for indigenous communities. Another possibility could be to order reparation measures related to the guarantee of non-repetition of violence against human rights defenders or the obligation to investigate and prosecute acts of violence $^{74}$. It would also be possible to issue precautionary measures ordering protective measures for indigenous leaderships while the case is still under the Court's jurisdiction $^{75}$

\subsection{The American Declaration of the Rights of Indigenous Peoples}

The American Declaration of the Rights of Indigenous Peoples (hereafter, ADRIP) was approved on June 15, 2016 by the General Assembly of the Organization of American States after seventeen years of negotiation. The only indigenous case decided by the Court after the Declaration is Xucuru v. Brazil and, oddly, it does not mention the Declaration. In the jurisprudence of the Court, it was cited only once in a concurring opi-

ments/annual-reports/256-report-ga2018 Access on: 27 Nov. 2018. 73 CORREIA, Joel E.; GILBERT, Jeremie; SUBRAMANIAM, Yogeswaran. Strategic litigation impacts: indigenous peoples land rights. New York: Open Society Foundations, 2017.

${ }^{74}$ It is not the purpose of the present article to offer a final solution for the question, as it may depend from future research in the field. It is intentioned only to present a point that demands further attention of the Court.

75 BERISTAÍN, Carlos Martin. Diálogos sobre la reparación: qué reparar en los casos de violaciones de derechos humanos. Quito: Instituto Interamericano de Derechos Humanos, 2009. p. 474. nion, in the Xákmok Kásek vs. Paraguay $\operatorname{case}^{76}$, when it was still a draft.

The ADRIP enshrines multiple rights, constructed upon the principle of indigenous peoples' self-determination. Some of the rights protected include the right to freely pursue their economic, social and cultural development (Art. 3), the right to cultural identity (arts. 7 and 13), the right to juridical personality (Art. 9), social rights (arts. 15, 17, 18, 19 and 27), rights of association, assembly, and freedom of expression and thought (art. $20)$, right to use, control and enjoyment over their territory (arts. 25 and 26$)^{77}$.

The consolidated jurisprudence of the Court regarding indigenous peoples fortified these rights for over seventeen years, allowing a perfect equivalence to exist between the rights established in the Declaration and the ones affirmed in the Court's jurisprudence. The mention of the ADRIP in the Xucuru case could have reinforced States' obligations regarding traditional peoples, as well as strengthened the rights recognized in the judgment.

A similar situation occurred when the UNDRIP was approved in 2007. The Court already had a consolidated jurisprudence in territorial rights, and the UNDRIP confirmed them. Two months after the adoption of the UNDRIP, the Court applied it to interpret the American Convention in the judgment of the Saramaka case. So far, the UNDRIP has been mentioned in all indigenous cases judged by the Court.

One could argue that the legal status of the Declaration, a soft law treaty, would justify the absence, or that the analysis of the Declaration would be beyond the jurisdiction ratione materiae of the Court. However, the Declaration composes the so-called corpus iuris of indigenous international law, and could be used to interpret

${ }_{76}$ IACtHR. Case of the Xákmok Kásek Indigenous Community. v. Paraguay. Merits, Reparations and Costs. August 24, 2010. Concurring Vote of Judge Eduardo Vio Grossi. SS5-6 and 20.

77 Further analysis about the ADRIP can be found in: Ordóñez Cifuentes, José Emilio Rolando (ed.). Análisis interdisciplinario de la Declaración Americana de los Derechos de los Pueblos Indigenas. Ciudad del México: UNAM, 2010; ERRICO, Stefania. The American Declaration on the Rights of Indigenous Peoples. Asil Insights, v. 21, n. 7, 2017. Available at: https://www.asil.org/insights/volume/21/ issue/7/american-declaration-rights-indigenous-peoples. Access on: 28 Dec. 2018; FUENZALIDA, Nancy Yánez. OAS: Regressive elements in the American Declaration. Available at: https:// www.iwgia.org/en/focus/global-governance/2422-oas-regressiveelements-in-the-american-declaratio. Access on: 3 Mar. 2019. 
the Convention, especially Article 21. Soft law treaties are frequently mentioned in Court decisions through Article 29.b of the Convention. In the present case, the judgment mentioned the UNDRIP as a body of the corpus iuris. In other indigenous cases, non-binding treaties, both regional and international, were also mentioned. To mention just a few examples: the American Declaration of the Rights and Duties of the Man, the Protocol of San Salvador ${ }^{78}$, the Declaration on Environment and Development ${ }^{79}$ and Guiding Principles on Business and Human Rights ${ }^{80}$.

\subsection{Reparation measures}

Besides the absences in the recognition of substantive rights presented above, another central concern in the Xucuru case is the fragility of the reparation measures ordered, both qualitatively and quantitatively.

Regarding the number of orders issued, the Court issued only three measures: one of compensation, one of restitution and one of satisfaction. There was no measure of non-repetition issued, nor the obligation to investigate and prosecute. In indigenous territorial cases, the average number of orders issued is 6.4. In fact, the only time the Court issued only three measures was in the precursor decision Mayagna (Sumo) Awas Tigni, back in 2001.

Historically the Court has built a complex system of reparation, and one of its defining characteristics is the commitment to non-monetary remedies, as these forward-looking measures are efficient and less expensive than economic compensation ${ }^{81}$. The Court has adopted the principle of integral reparation, responding to each aspect of damage caused to the communities. However, such principle cannot be observed in the present case, as it is characterized by a preponderance of economic

\footnotetext{
8 IACtHR. Case of the Yakye Axa Indigenous Community v. Paraguay. Merits, Reparations and Costs. June 17, 2005, \$163; IACtHR. Case of the Xákmok Kásek Indigenous Community. v. Paraguay. Merits, Reparations and Costs. August 24, 2010, \$211; IACtHR. Case of the Kaliña and Lokono Peoples v. Suriname. Merits, Reparations and Costs. November 25, 2015, \$172.

79 IACtHR. Case of Kichwa Indigenous People of Sarayaku v. Ecuador. Merits and reparations. June 27, 2012.

80 IACtHR. Case of the Kaliña and Lokono Peoples v. Suriname. Merits, Reparations and Costs. November 25, 2015.

81 BERISTAÍN, Carlos Martin. Diálogos sobre la reparación: qué reparar en los casos de violaciones de derechos humanos. Quito: Instituto Interamericano de Derechos Humanos, 2009. p. 173.
}

measures.

Some remedies issued in past cases could have been adequate for the Xucuru community in order to redress human rights violations, for example, the celebration of a public act of acknowledgement of international responsibility for the violations ${ }^{82}$ and the creation of training programs on the rights of indigenous peoples ${ }^{83}$. Moreover, considering the specific situation of violence against indigenous leadership, the Court could have determined security measures, such as the inclusion/ maintenance of Xucuru leadership in a state program for protection or the development/reinforcement of public policies for the protection of human rights defenders and indigenous leadership, or even the investigation of violent acts against the community (non-repetition measures).

From another perspective, regarding the extension of applied measures, research demonstrates a setback in the ordered remedies when compared to past cases, as well as their inability to fully redress human rights violations against the Xucuru people.

The central measure applied was the restitution order, determining the final delivery of the territory ( $s a$ neamiento), removing any obstacle or interference over the traditional land and guaranteeing the Xucuru people the effective and total control over their territory in a term of eighteen months. The restauration remedy attended to the demand of the representatives and is similar to orders issued in former similar cases ${ }^{84}$.

82 IACtHR. Case of the Moiwana Community v. Suriname. Preliminary Objections, Merits, Reparations and Costs. June 15, 2005, S\$216-217; IACtHR. Case of the Yakye Axa Indigenous Community v. Paraguay. Merits, Reparations and Costs. June 17, 2005, 125, \$226; IACtHR. Case of the Xákmok Kásek Indigenous Community. v. Paraguay. Merits, Reparations and Costs. August 24, 2010, $\$ 296-297$; IACtHR. Case of Kichwa Indigenous People of Sarayaku v. Ecuador. Merits and reparations. June 27, 2012, \$\$303-305; IACtHR. Case of the Afro-descendant Communities displaced from the Cacarica River Basin (Operation Genesis) v. Colombia. Preliminary Objections, Merits, Reparations and Costs. November 20, 2013, \446-447; IACtHR. Case of the Kuna Indigenous People of Madungandí and the Emberá Indigenous People of Bayano and their members v. Panama. Preliminary Objections, Merits, Reparations and Costs. October 14, 2014, \$\$218-219

83 IACtHR. Case of Kichwa Indigenous People of Sarayaku v. Ecuador. Merits and reparations. June 27, 2012; IACtHR. Case of the Kaliña and Lokono Peoples v. Suriname. Merits, Reparations and Costs. November 25, 2015.

${ }^{84}$ IACtHR. Case of the Community Garifuna Triunfo de la Cruz and its members v. Honduras. Merits, Reparations and Costs. October 8, 2015, \$\$258-264; IACtHR. Case of Garífuna Punta Piedra Community and its members v. Honduras. Preliminary Objections, 
However, the Court considered the eventual impossibility of full or partial territorial restitution due to private occupation. In this situation, the Court ordered the State to buy or to expropriate the land or to offer alternative lands to the communities with their consent.

The possibility of alternative lands in exchange for traditional territory may be considered inadequate for two main reasons. First, there is an incompatibility of this remedy with the recognition of the community's property rights. The Court had affirmed that there was no controversy regarding the property rights of the $\mathrm{Xu}$ curu over their territory, and the State had the duty to perform saneamiento. Therefore, the Court considered it inadequate to discuss conflicts between private and communal property, as the Brazilian legislation assured prominence of the collective property right over the private property ${ }^{85}$ (topic 3.3, supra). Contradicting the recognition of the substantive right in the merit analysis, the Court permitted the State to offer alternative lands in the reparation measures.

Second, the offer of alternative lands contrasts with the recognition of the special relationship between indigenous peoples and their land, characterized by profound cultural and religious bounds. For indigenous peoples, the territory is not merely a geographical space that can be exchanged, but is instead an indispensable mean for their cultural and physical survival. Such contradictions have been appointed by several authors in similar cases $^{86}$, demonstrating a pattern in which the Court seems to ignore the distinction between land and territory and the impossibility to substitute spiritual and cultural relations with traditional territory.

Moving on, regarding the satisfaction measure issued (publication of the judgment), it represents a lower level

Merits, Reparations and Costs. October 8, 2015, \$\$322-326

85 IACtHR. Case of the Xucuru Indigenous People and its members v. Brazil. Preliminary Objections, Merits, Reparations and Costs. February 5, 2017, $\int \$ 125-127$

86 GÓNGORA MAAS, Juan Jésus; QUINTERO, Gerardo Mata. La obligación de saneamiento en el caso de la comunidad de Punta Piedra y sus miembros vs. Honduras. territorios, cuerpos y diferencia. In: JOAQUÍN, A. Mejia R. (ed.). Obligaciones internacionales del estado de Honduras en materia de derechos humanos y bienes naturales. Yoro: ERIC-SJ, 2018. p. 346-371. p. 358; DULITZKY, Ariel. When afrodescendants became "tribal peoples": the inter-American human rights system and rural black communities. UCLA Journal of International Law and Foreign Affairs, San Francisco, v. 15, p. 29-81, 2010. p. 49-52; SHELTON, Dinah. The Inter-American Human Rights law of indigenous peoples. Harvard Law Review, Cambridge, v. 35, p. 937-980, 2013. p. 970. of dissemination of the decision than other cases and a restricted reach in Brazil. Publication of the decision is a very common order issued by the Court and it has the essential role of disseminating the content of the decision and raising awareness of the population regarding indigenous rights. Additionally, studies have associated high levels of media coverage with faster compliance by the States, as they strengthen social pressure for the fulfilment of the decision ${ }^{87}$.

In the Xucuru case, the Court ordered the publication of the judgment online on the government webpage and in the official gazette, which is accessible online. The representatives had demanded that it be broadcast on TV and radio, as well as published in local and national newspapers.

In almost all indigenous territorial cases $^{88}$, publication of the decision was ordered as a measure of satisfaction. In all ten cases in which it was ordered ${ }^{89}$, the Court ordered its publication in the official gazette and in a newspaper of national circulation. Except in the Operation Genesis case, the Court also ordered broadcasts on radio with widespread coverage among the community and, since 2010, the Court has ordered the publication of the decision on the government website.

87 CAVALLARO, James; SCHAFFER, Emily J. Less as more: rethinking supranational litigation of economic and social rights in the Americas. Hastings Law Journal, San Francisco, v. 2, n. 56, p. 217-281, 2004.

88 The exceptions are the cases Mayagna (Sumo) Awas Tingni and Moiwana, the first two cases.

89 IACtHR. Case of the Yakye Axa Indigenous Community v. Paraguay. Merits, Reparations and Costs. June 17, 2005, \$227; IACtHR. Case of the Sawhoyamaxa Indigenous Community v. Paraguay. Merits, Reparations and Costs. March 29, 2006, \$236; IACtHR. Case of the Saramaka People. v. Suriname. Preliminary Objections, Merits, Reparations, and Costs. November 28, 2007, \$196; IACtHR. Case of the Xákmok Kásek Indigenous Community. v. Paraguay. Merits, Reparations and Costs. August 24, 2010, \$298-299; IACtHR. Case of Kichwa Indigenous People of Sarayaku v. Ecuador. Merits and reparations. June 27, 2012. Series C No. 245, s\$307-308; IACtHR. Case of the Afro-descendant Communities displaced from the Cacarica River Basin (Operation Genesis) v. Colombia. Preliminary Objections, Merits, Reparations and Costs. November 20, 2013, $\$ 445 ;$ IACtHR. Case of the Kuna Indigenous People of Madungandí and the Emberá Indigenous People of Bayano and their members v. Panama. Preliminary Objections, Merits, Reparations and Costs. October 14, 2014, \$\$216-217; IACtHR. Case of Garífuna Punta Piedra Community and its members v. Honduras. Preliminary Objections, Merits, Reparations and Costs. October 8, 2015. Series C No. 304, \$\$338-339; IACtHR. Case of the Community Garifuna Triunfo de la Cruz and its members v. Honduras. Merits, Reparations and Costs. October 8, 2015, \$\$271-272; IACtHR. Case of the Kaliña and Lokono Peoples v. Suriname. Merits, Reparations and Costs. November 25, 2015, \$312-313. 
It is unclear as to why the Court in the present case did not order the decision to be broadcasted on the radio and published in a national newspaper.

The measures of publication ordered in the present case have a restricted reach, as they usually depend on an active behaviour of a citizen to access the information, as well as access to the internet ${ }^{90}$. In contraposition, broadcasting on the radio and publication in national newspapers reaches a wider public, mainly in areas with limited access to internet.

Lastly, regarding the compensation measure, the Court maintained a pattern consolidated in former cases and criticized for its paternalistic point of view. Pecuniary compensation was ordered in all indigenous territorial cases and, in almost all of them, by the creation of a development fund ${ }^{91}$. The average payment for compensation is US\$1,127,500.0092 and in the Xucuru

\footnotetext{
90 Recent data from the Brazilian Institute of Geography and Statistics (IBGE) estimates that only $27,4 \%$ of the rural domiciles in the Northeast region in Brazil (where the community is located) have access to internet. INTITUTO BRASILEIRO DE GEOGRAFIA E ESTATÍSTICA. Acesso à internet e à televisão e posse de telefone móvel celular pra uso pessoal: análise dos resultados. Brasília: IBGE, 2018. p. 16 91 In the first case, the Court ordered the State to invest directly the money in works or services of the community's interest. IACtHR. Case of the Mayagna (Sumo) Awas Tingni Community v. Nicaragua. Preliminary Objections. February 1, 2000, \$S213-215. In two occasions, the payment was ordered directly to the community leadership or association: IACtHR. Case of Kichwa Indigenous People of Sarayaku v. Ecuador. Merits and reparations. June 27, 2012, S\$322-323 and IACtHR. Case of the Kuna Indigenous People of Madungandí and the Emberá Indigenous People of Bayano and their members v. Panama. Preliminary Objections, Merits, Reparations and Costs. October 14, 2014, \$\$237-247. In eight cases, the Court ordered the creation of a development fund, five of them managed by a tripartite committee (IACtHR. Case of the Moiwana Community v. Suriname. Preliminary Objections, Merits, Reparations and Costs. June 15, 2005, $\$ \$ 213-215$; IACtHR. Case of the Yakye Axa Indigenous Community v. Paraguay. Merits, Reparations and Costs. June 17, 2005. Series C No. 125, DS199-206; IACtHR. Case of the Sawhoyamaxa Indigenous Community v. Paraguay. Merits, Reparations and Costs. March 29, 2006, \$\$219-225; IACtHR. Case of the Saramaka People. v. Suriname. Preliminary Objections, Merits, Reparations, and Costs. November 28, 2007, \$\$200-202; and IACtHR. Case of the Xákmok Kásek Indigenous Community. v. Paraguay. Merits, Reparations and Costs. August 24, 2010, SS319324 ) and three of them managed by the State with participation of an indigenous representative (IACtHR. Case of Garífuna Punta Piedra Community and its members v. Honduras. Preliminary Objections, Merits, Reparations and Costs. October 8, 2015, \$S322-336; IACtHR. Case of the Community Garifuna Triunfo de la Cruz and its members v. Honduras. Merits, Reparations and Costs. October 8, 2015, S\$295-299; IACtHR. Case of the Kaliña and Lokono Peoples v. Suriname. Merits, Reparations and Costs. November 25, 2015, \$(295-299).
}

92 Average of collective compensation issued in the twelve indig- case, US\$1,000,000.00 was issued, which is very close to the average. The difference in payment is related to factual circumstances and the gravity of the violation ${ }^{93}$.

Several authors have criticized the creation of development funds, instead of the direct delivery of the money to the community ${ }^{94}$. The Court's remedy is considered paternalistic, as it underestimates the capacity of indigenous communities to manage the money on their own and the administration of the fund is relegated to a tripartite committee or directly to the State ${ }^{95}$. There is also a discrepancy regarding the recognition of the right to self-determination of indigenous peoples, infringing on their right to freely pursue their social, economic and cultural development ${ }^{96}$.

In the present case, contrary to previous decisions, the Court did not make any consideration regarding how the fund shall be managed, addressing only the

enous territorial cases, regarding pecuniary and non-pecuniary damages. The Operation Genesis case was excluded from the average, as there was no collective compensation order. Individual compensations for the death of next of kin were also excluded.

93 Antkowiak criticizes the value of the compensation in indigenous cases in comparison with a case regarding compensation for violation of right to private property. In Salvador-Chiriboga v. Ecuador, the Court issued a compensation of US\$18,7 million, the market value. Such evaluation was never performed in an indigenous cases, demonstrating a different pattern in the Court regarding private or communal property. In the words of the author, "private landowners obtain millions, while indigenous peoples receive condescending gestures of charity in the form of developmental programs". ANTKOWIAK, Thomas M. A dark side of virtue: the Inter-American Court and reparations for indigenous peoples. Duke J. Comp. \& Int'l L, v. 25, p. 1-80, 2014. p. 69-70

94 ANTKOWIAK, Thomas M. A dark side of virtue: the InterAmerican Court and reparations for indigenous peoples. Duke J. Comp. \& Int'l L, v. 25, p. 1-80, 2014. p. 77-79. DULITZKY, Ariel. When afro-descendants became "tribal peoples": the inter-American human rights system and rural black communities. UCL A Journal of International Law and Foreign Affairs, San Francisco, v. 15, p. 29-81, 2010. 53-54; ROBLES G., Magda Yadira. La compensación colectiva en la Corte IDH. a propósito de la sentencia Triunfo de la Cruz y sus miembros vs. Honduras. In: JOAQUÍN, A. Mejia R. (ed.). Obligaciones internacionales del estado de Honduras en materia de derechos bumanos y bienes naturales. Yoro: ERIC-SJ, 2018. p. 315-345. p. 340.

95 In the cases Yakye Axa and Sawhoyamaxa, both against Paraguay, the development fund was object to misappropriation by State agents The public employee Rubén Darío Quesnel was condemned for ten years in jail for diversion of nearly USD 530.000 from the indigenous development fund. EXTITULAR del Indi, Rubén Quesnel, condenado a 10 años de cárcel. Ultima Hora, Assunción, Aug. 2018. Available at: https://www.ultimahora.com/ex-titulardel-indi-ruben-quesnel-condenado-10-anos-carcel-n2704182.html. Access on: 6 Dec. 2018.

96 Apart from indigenous cases, the Court has determined payment through development fund only in cases of minors or legally incapacitated. 
obligation to consult with the community. As this issue is relegated to the State's discretion, it may generate uncertainties and conflicts with the indigenous community. The remedy may not attend to the community's will regarding its development, and thus aggravate the existing conflict with the State.

In conclusion, regarding the analysis of reparation measures, Antkowiak suggests a victim-centred approach in the restauration system applied to indigenous peoples. According to the author, their demands must be heard, even though it is not always possible to fully attend to them. Using this approach, the Court immerses itself in the communities' reality, and can tailor remedies more precisely to violations ${ }^{97}$. Contrary to this position, in the case at hand, the representatives demanded twelve measures that they considered adequate and the Court attended fully to only two of them: the creation of the development fund and the reimbursement of fees and $\operatorname{costs}^{98}$.

\subsection{Identification of injured parties}

In the judgment of the Xucuru case, the Court identified the indigenous people Xucuru as the sole injured party, arguing that the community was the victim of the violation of rights ${ }^{99}$. However, in former cases, the Court had considered both the community and its members as injured parties, recognizing that human rights violations may simultaneously affect individual and collective spheres ${ }^{100}$. As the former president of

\footnotetext{
${ }_{97}$ ANTKOWIAK, Thomas M. A dark side of virtue: the InterAmerican Court and reparations for indigenous peoples. Duke J. Comp. \& Int'l L, v. 25, p. 1-80, 2014. p. 49

98 The representatives only demanded reparations in the final allegations, as they did not present brief of demands, arguments and evidence. The Court considered the demand extemporaneous and did not analyze it.

99 IACtHR. Case of the Xucuru Indigenous People and its members v. Brazil. Preliminary Objections, Merits, Reparations and Costs. February 5, 2017, $\$ \$ 187$ and 220.3-4.

100 IACtHR. Case of the Kuna Indigenous People of Madungandí and the Emberá Indigenous People of Bayano and their members v. Panama. Preliminary Objections, Merits, Reparations and Costs. October 14, 2014. \$209 and Operative paragraphs 4-7; IACtHR. Case of Garífuna Punta Piedra Community and its members v. Honduras. Preliminary Objections, Merits, Reparations and Costs. October 8, 2015, \$\$317 and 372.4-6; IACtHR. Case of the Community Garífuna Triunfo de la Cruz and its members v. Honduras. Merits, Reparations and Costs. October 8, 2015, \$257 and Operative paragraphs 1-3; IACtHR. Case of the Kaliña and Lokono Peoples v. Suriname. Merits, Reparations and Costs. November 25, 2015, $\int § 273$ and 329.1-3
}

the Court, Judge García-Ramirez asserted in a separate opinion, "There is an intimate and inextricable link between individual and collective rights; a linkage that is a condition sine qua non for the genuine protection of persons belonging to indigenous ethnic groups." 101

The recognition of a collective personality as an injured party has been a celebrated breakthrough exclusive to indigenous cases in the Inter-American Court, overcoming a strict interpretation of Article 1.2 ("For the purposes of this Convention, "person" means every human being"') ${ }^{102}$.

The Court did not present any justification for the exclusion of the members as co-victims of the violations. Neither the Commission nor the Representatives made specific demands regarding the recognition of an injured party.

The identification of the injured party is a central step towards the application of remedies, which are fundamental for the full restauration of violated rights. Considering the complexity of indigenous demands, both individual and collective rights must be fully repaired by adequate remedies, demanding a correct identification of injured parties. The collective consideration may not disregard the individual damage suffered by the members of the community, mainly in situations of widespread violence against indigenous members.

In the Xucuru case, the Court could have offered a wider protection of human rights if it had recognized both the community and its members as injured parties, just as it was recognized in the Garífunas v. Honduras cases in very similar circumstances. It is essential that the collective protection of human rights does not undermine the individual sphere of rights, as they are intrinsically related.

101 IACtHR. Case of the Yakye Axa Indigenous Community v. Paraguay. Merits, Reparations and Costs. June 17, 2005. Concurring Opinion of Judge Sergio García Ramírez, \14.

102 For a deeper analysis on the evolution of the Court interpretation regarding the recognition of the collective personality, see: RUSSO, Anna Margherita; WENCES, Isabel. De los derechos de los miembros de las comunidades a los derechos de la comunidad y sus miembros: la diversidad cultural y el reconocimiento de la propriedad colectiva de los pueblos indigenas en la Corte Interamericana de Derechos Humanos. In: SANTOLAYA MACHETTI, P.; WENCES, I. (org.). La América de los derechos. Madrid: Centro de Estudios Políticos y Constitucionales, 2016. p. 281-325. 


\subsection{Low impact of the decision in Brazil}

Besides the above-mentioned deficiencies in the decision, a lack of reception of the judgment in the domestic sphere was also notable.

First, the decision was followed by the absence of official manifestation from the government or its ministries. Contrary to other cases ${ }^{103}$, the Ministry of Foreign Affairs did not issue any press release and, when asked by the press to comment on the decision, the government did not provide an answer ${ }^{104}$.

The media coverage in the national sphere was also faint. Four of the six most read newspapers in the country did not announce the judgement at all (Folba de São Paulo, Super Noticia, Zero Hora and Extra) ${ }^{105}$. The newspaper Globo published a very brief article ${ }^{106}$ and the newspaper Estadão contacted one of the victims' representatives ${ }^{107}$. A more detailed report of the decision, including its factual background and interviews with the victims, were published in Portuguese only by foreign newspapers: the Spanish El Pais ${ }^{108}$ and the Portuguese Diário de Notícias ${ }^{109}$.

\footnotetext{
103 In the case Vladimir Herzog, for example, the Court's decision generated a prompt press release applauding the judgement and enhancing the importance of its compliance. MRE. Press Release n. 233, Jun. 2018. Available at: http://www.itamaraty.gov.br/index. php?option $=$ com_content $\&$ view $=$ category\&id $=42 \&$ Itemid $=280 \&$ lang=pt-BR. Access on: Dec. 062018.

104 VALENTE, Jonas. Corte Interamericana responsabiliza Brasil por desrespeito a direitos indígenas. Agencia Brasil, Mar. 2018 Available at: http://agenciabrasil.ebc.com.br/direitos-humanos/ noticia/2018-03/corte-interamericana-responsabiliza-brasil-pordesrespeitar. Access on: 27 Nov. 2018; CORTE Interamericana de Direitos Humanos condena Brasil por violação de direitos de índios. O Globo, Mar. 2018. Available at: https://oglobo.globo.com/brasil/ corte-interamericana-de-direitos-humanos-condena-brasil-por-violacao-de-direitos-de-indios-22483039. Access on: 6 Dec. 2018.

105 According to research in the online version of the newspapers for the terms "Xucuru", "Corte Interamericana" and "Xukuru".

106 CORTE Interamericana de Direitos Humanos condena Brasil por violação de direitos de índios. O Globo, Mar. 2018. Available at: https://oglobo.globo.com/brasil/corte-interamericana-de-direitos-humanos-condena-brasil-por-violacao-de-direitos-de-indios-22483039. Access on: 6 Dec. 2018.

107 BORGES, André. Brasil é condenado em processo de demarcação de terra indígena. Estadão, 2018. Available at: https://politica. estadao.com.br/noticias/geral,brasil-e-condenado-em-processode-demarcacao-de-terra-indigena,70002227751. Access on: 6 Dec. 2018.

108 OLIVEIRA, Regiane. Os indígenas que derrotaram o Governo brasileiro na Corte Interamericana. El País, Mar. 2018. Available at: https://brasil.elpais.com/brasil/2018/03/13/politica/1520949894_800892.htmlAccess on: 6 Dec. 2018.

109 MOREIRA, Joao Almeida. Brasil vai pagar um milhão de
}

The apparent lack of interest in the decision may be explained by the general situation of the invizibilization and marginalization of indigenous peoples in the country and it may have negative impacts on the implementation of the decision. As already mentioned, media coverage is essential for disseminating the content of the decision, redressing the violation and raising the awareness of the population regarding indigenous rights, and forcing the State to respond with full compliance. ${ }^{110}$

\section{Final conclusions}

The Inter-American Court has a remarkable jurisprudence regarding indigenous rights, influencing both international and domestic legal systems, as well as redressing centuries of marginalization and exploitation suffered by traditional communities. The Court has not only expanded classical rights guaranteed in the Convention by interpretational means, namely, the right to property and the right to juridical protection; it has also recognized implicit rights as the rights to cultural identity, self-determination and prior consultation. The reach of the innovations brought about by the Court goes beyond indigenous protection, reinforcing the human rights system as a whole.

The Xucuru case is a consolidation of indigenous jurisprudence after seventeen years of strategic litigation, clarifying and fortifying indigenous rights in the inter-American system. However, the decision may represent in some aspects a setback in the jurisprudence

dólares a índios Xucuru. Diário de Notícias, São Paulo, Mar. 2018. Available at: https://www.dn.pt/mundo/interior/brasil-vai-pagarum-milhao-de-dolares-a-indios-xucuru-9201580.html. Access on: 6 Dec. 2018 .

110 Study demonstrated that media coverage of the Inter-American System in general is low, except when directly involves the particular country and, even then, coverage is sparse, contributing to "little hope of penetrating deeply into Latin American legal culture". Gil, Diego; Garcia, Rolando; Friedman, Lawrence M. Media representations of the Inter-American System of Human Rights. In: Fortes, P.; Boratti, L. V.; Palacios Lleras, A.; Daly, T. G. (org.). Law and policy in Latin America: transforming courts, institutions, and rights, London: Palgrave Macmillan, 2017. p. 57-71. In a comparative perspective, in a case study regarding land rights' decisions from the IACtHR against Paraguay (cases Yakye Axa, Sawhoyamaxa and Xákmok Kásek), researchers concluded that mainstream media coverage was limited and "few people in Paraguay know about the litigation". CORREIA, Joel E.; GILBERT, Jeremie; SUBRAMANIAM, Yogeswaran. Strategic litigation impacts: indigenous peoples land rights. New York: Open Society Foundations, 2017. p. 63-64. 
and, in others, a lost opportunity to deepen the protection of indigenous rights.

After briefly presenting the Court jurisprudential protection of indigenous traditional territory, this article analysed the points of consolidation brought about by the decision, followed by an enumeration of problematic issues in the judgment, namely the absence of protection of indigenous leadership, non-mention of the ADRIP, narrowness of the reparation measures and the lack of recognition of individuals as injured parties.

The Xucuru case should not be considered as an isolated case, but instead immersed in a wider system of strategic litigation; a major characteristic of the Inter-American System of Human Rights. Constrained by severe budgetary limits, the Court has developed a creative jurisprudence commended by its capacity to recognize and redress structural patterns of violation; a task that has been carried on by two main strategies: the contextual analysis of each case and the issue of non-repetition orders. This model of litigation has impacted not only the parties directly involved in the litigation, but also countries and victims elsewhere ${ }^{111}$.

In the case under analysis, it is essential to bear in mind that the Xucuru struggle is part of a structural pattern of marginalization and exclusion of indigenous peoples. Even though only the Xucuru case has reached the Court, it is safe to affirm in the Brazilian context that hundreds of indigenous communities suffer due to a lack of property protection, as well as due to violence against indigenous leadership. The Xucuru case represented a lost opportunity to redress a pattern of marginalization and exclusion of indigenous peoples in the Brazilian context, thus failing the strategic litigation system.

\footnotetext{
111 BURGORGUE-LARSEN, Laurence. Inter-American added value. In: BOGDANDY, A. V.; FERRER MAC-GREGOR, E.; MORALES ANTONIAZZI, M.; PIOVESAN, F. (org.). Transformative constitutionalism in Latin America: the emergence of a New Ius Commune. Oxford United Kingdom: Oxford University Press, 2017. p. 377-408; Alessandri, Paulo Saavedra. Algunas reflecciones encuanto el impacto estructural de las decisiones de la Corte Interamericana de Derechos Humanos. In: Ugartemendia Eceizabarrena, J. I.; Saiz Arnaiz, A.; Morales Antoniazzi, M. (org.). La garantía jurisdiccional de los Derechos Humanos: un estudio comparado de los sistemas regionales de tutela, europeo, interamericano y africano. Oñati [Guipuzkoa]: Instituto Vasco de Administración Pública, 2015. p. 226-258; Sikkink, Kathryn; Walling, Carrie Booth. The impact of human rights trials in Latin America. Journal of Peace Research, v. 44, n. 4, p. 427-445, 2007.
}

\section{References}

Alessandri, Paulo Saavedra. Algunas reflecciones encuanto el impacto estructural de las decisiones de la Corte Interamericana de Derechos Humanos. In: Ugartemendia Eceizabarrena, J. I.; Saiz Arnaiz, A.; Morales Antoniazzi, M. (org.). La garantía jurisdiccional de los Derechos Humanos: un estudio comparado de los sistemas regionales de tutela, europeo, interamericano y africano. Oñati [Guipuzkoa]: Instituto Vasco de Administración Pública, 2015. p. 226-258.

ANTKOWIAK, Thomas M. A dark side of virtue: the Inter-American Court and reparations for indigenous peoples. Duke J. Comp. \& Int'l L, v. 25, p. 1-80, 2014.

ANTKOWIAK, Thomas M. Rights, resources and rhetoric: indigenous peoples and the Inter-American Court. University of Pennsylvania Journal of International Law, Philadelphia, v. 33, n. 1, p. 113-187, 2014.

BERISTAÍN, Carlos Martin. Diálogos sobre la reparación: qué reparar en los casos de violaciones de derechos humanos. Quito: Instituto Interamericano de Derechos Humanos, 2009.

Bernardes, Marcia Nina. Sistema Interamericano de Direitos Humanos como esfera pública transnacional: aspectos jurídicos e políticos da implementação de decisões internacionais. Sur - Revista Internacional de Direitos Humanos, São Paulo, v. 8, n. 15, p. 135-156, 2011.

BORGES, André. Brasil é condenado em processo de demarcação de terra indígena. Estadão, 2018. Available at: https://politica.estadao.com.br/noticias/ geral,brasil-e-condenado-em-processo-de-demarcacaode-terra-indigena, 70002227751. Access on: 6 Dec. 2018.

BURGORGUE-LARSEN, Laurence. Inter-American added value. In: BOGDANDY, A. V.; FERRER MACGREGOR, E.; MORALES ANTONIAZZI, M.; PIOVESAN, F. (org.). Transformative constitutionalism in Latin America: the emergence of a New Ius Commune. Oxford United Kingdom: Oxford University Press, 2017. p. $377-408$.

CAVALLARO, James; SCHAFFER, Emily J. Less as more: rethinking supranational litigation of economic and social rights in the Americas. Hastings Law Journal, San Francisco, v. 2, n. 56, p. 217-281, 2004. 
CONSELHO INDIGENISTA MISSIONÁRIO; CAVALLI, Guilherme (ed.). Congresso Anti-Indigena: os parlamentares que mais atuaram contra os direitos dos povos indígenas. Available at: https://cimi.org.br/wpcontent/uploads/2018/09/congresso-anti-indigena. pdf. Access on: 27 Nov. 2018.

CORREIA, Joel E.; GILBERT, Jeremie; SUBRAMANIAM, Yogeswaran. Strategic litigation impacts: indigenous peoples land rights. New York: Open Society Foundations, 2017.

CORTE Interamericana de Direitos Humanos condena Brasil por violação de direitos de índios. O Globo, Mar. 2018. Available at: https://oglobo.globo.com/brasil/ corte-interamericana-de-direitos-humanos-condenabrasil-por-violacao-de-direitos-de-indios-22483039. Access on: 6 Dec. 2018.

DULITZKY, Ariel. When afro-descendants became "tribal peoples": the inter-American human rights system and rural black communities. UCLA Journal of International Law and Foreign Affairs, San Francisco, v. 15, p. 29-81, 2010.

ERRICO, Stefania. The American Declaration on the Rights of Indigenous Peoples. Asil Insights, v. 21, n. 7, 2017. Available at: https://www.asil.org/insights/volume/21/issue/7/american-declaration-rights-indigenous-peoples. Access on: 28 Dec. 2018.

EXTITULAR del Indi, Rubén Quesnel, condenado a 10 años de cárcel. Ultima Hora, Assunción, Aug. 2018. Available at: https://www.ultimahora.com/ex-titulardel-indi-ruben-quesnel-condenado-10-anos-carceln2704182.html. Access on: 6 Dec. 2018.

FUENZALIDA, Nancy Yánez. OAS: Regressive elements in the American Declaration. Available at: https:/ / www.iwgia.org/en/focus/global-governance/2422oas-regressive-elements-in-the-american-declaratio. Access on: 3 Mar. 2019.

Gil, Diego; Garcia, Rolando; Friedman, Lawrence M. Media representations of the Inter-American System of Human Rights. In: Fortes, P.; Boratti, L. V.; Palacios Lleras, A.; Daly, T. G. (org.). Law and policy in Latin America: transforming courts, institutions, and rights, London: Palgrave Macmillan, 2017. p. 57-71.

GLOBAL WITNESS. A que custo? Negocios irresponsables y el asesinato de personas defensoras de la tierra y del medio ambiente en 2017, 2018. Available at: https://www.globalwitness.org/en/campaigns/environmental-activists/defenders-annual-report/. Access on: 27 Nov. 2018.

GÓNGORA MAAS, Juan Jésus; QUINTERO, Gerardo Mata. La obligación de saneamiento en el caso de la comunidad de Punta Piedra y sus miembros vs. Honduras. territorios, cuerpos y diferencia. In: JOAQUÍN, A. Mejia R. (ed.). Obligaciones internacionales del estado de Honduras en materia de derechos humanos y bienes naturales. Yoro: ERIC-SJ, 2018. p. 346-371.

IACHR. Case of Garifuna Punta Piedra Community and its members v. Honduras. Preliminary Objections, Merits, Reparations and Costs. October 8, 2015.

IACHR. Case of Kichwa Indigenous People of Sarayaku v. Ecuador. Merits and reparations. June 27, 2012.

IACHR. Case of the Afro-descendant Communities displaced from the Cacarica River Basin (Operation Genesis) v. Colombia. Preliminary Objections, Merits, Reparations and Costs. November 20, 2013.

IACHR. Case of the Community Garifuna Triunfo de la Cruz and its members v. Honduras. Merits, Reparations and Costs. October 8, 2015.

IACHR. Case of the Kalina and Lokono Peoples v. Suriname. Merits, Reparations and Costs. November 25, 2015

IACHR. Case of the Kuna Indigenous People of Madungandi and the Emberá Indigenous People of Bayano and their members v. Panama. Preliminary Objections, Merits, Reparations and Costs. October 14, 2014.

IACHR. Case of the Moiwana Community v. Suriname. Preliminary Objections, Merits, Reparations and Costs. June 15, 2005.

IACHR. Case of the Saramaka People. v. Suriname. Preliminary Objections, Merits, Reparations, and Costs. November 28, 2007.

IACHR. Case of the Sawhoyamaxa Indigenous Community v. Paraguay. Merits, Reparations and Costs. March 29, 2006.

IACHR. Case of the Xákmok Kásek Indigenous Community. v. Paraguay. Merits, Reparations and Costs. August 24, 2010.

IACHR. Case of the Xucuru Indigenous People and its members v. Brazil. Preliminary Objections, Merits, Reparations and Costs. February 5, 2017. 
IACHR. Case of the Yakye Axa Indigenous Community v. Paraguay. Merits, Reparations and Costs. June 17, 2005.

IACHR. Informe n. 44/15. Caso 12.728, Informe de Fondo Povo Indigena Xucuru Brasil. July 282015.

IACtHR. Case of the Mayagna (Sumo) Awas Tingni Community v. Nicaragua. Preliminary Objections. February 1, 2000.

INSTITUTO SOCIOAMBIENTAL. Situação das terras indigenas no Brasil. Available at: https:/ / pib.socioambiental. org/pt/Situa\%C3\%A7\%C3\%A3o_jur\%C3\%ADdica_ das_TIs_no_Brasil_hoje. Access on: 12 Dec. 2018.

INTITUTO BRASILEIRO DE GEOGRAFIA E ESTATÍSTICA. Acesso à internet e à televisão e posse de telefone móvel celular pra uso pessoal: análise dos resultados. Brasília: IBGE, 2018.

LÓPEZ ESCARCENA, Sebastián. Un derecho jurisprudencial: la propiedad colectiva y la corte interamericana. Revista de derecho, Coquimbo, v. 24, n. 1, p. 133189, 2017.

Mazzuoli, Valério de Oliveira; Ribeiro, Dilton. Indigenous rights before the Inter-American Court of Human Rights: a call for a pro individual interpretation. The Transnational Human Rights Review, v. 2, n. 1, p. 32-62, 2015.

MOREIRA, Joao Almeida. Brasil vai pagar um milhão de dólares a índios Xucuru. Diário de Notícias, São Paulo, Mar. 2018. Available at: https://www.dn.pt/mundo/interior/brasil-vai-pagar-um-milhao-de-dolares-a-indiosxucuru-9201580.html. Access on: 6 Dec. 2018.

OLIVEIRA, Regiane. Os indígenas que derrotaram o Governo brasileiro na Corte Interamericana. El País, Mar. 2018. Available at: https://brasil.elpais.com/brasil/2018/03/13/politica/1520949894_800892.htmlAccess on: 6 Dec. 2018.

Ordóñez Cifuentes, José Emilio Rolando (ed.). Análisis interdisciplinario de la Declaración Americana de los Derechos de los Pueblos Indígenas. Ciudad del México: UNAM, 2010.

OSOWSKI, Raquel. O marco temporal para demarcação de terras indígenas, memória e esquecimento. $M e-$ diacoes, v. 22, n. 2, p. 320-346, Jul. 2017.

PASQUALUCCI, J. M. The Evolution of International indigenous rights in the Inter-American Human Rights System. Human Rights Law Review, v. 6, n. 2, p. 281-322, 2006.

ROBLES G., Magda Yadira. La compensación colectiva en la Corte IDH. a propósito de la sentencia Triunfo de la Cruz y sus miembros vs. Honduras. In: JOAQUÍN,
A. Mejia R. (ed.). Obligaciones internacionales del estado de Honduras en materia de derechos humanos y bienes naturales. Yoro: ERIC-SJ, 2018. p. 315-345.

RUIZ-CHIRIBOGA, Oswaldo; ROMAN, Gina. Pueblos indígenas y la corte interamericana de Derechos humanos: fondo y reparaciones. In: HAECK, Y.; RUIZCHIRIBOGA, O.; BURBANO Herrera, C. (org.). The Inter-American Court of Human Rights: theory and practice, present and future. Cambridge: Intersentia, 2015.

RUSSO, Anna Margherita; WENCES, Isabel. De los derechos de los miembros de las comunidades a los derechos de la comunidad y sus miembros: la diversidad cultural y el reconocimiento de la propriedad colectiva de los pueblos indigenas en la Corte Interamericana de Derechos Humanos. In: SANTOLAYA MACHETTI, P.; WENCES, I. (org.). La América de los derechos. Madrid: Centro de Estudios Políticos y Constitucionales, 2016. p. 281-325.

SANCHEZ, Nelson Camilo; CÉRON, Laura Lyons. El elefante en la sala: el retraso procesal en el sistema de peticiones individuales del sistema interamericano. In: DEJUSTICIA. Desafíos del sistema interamericano de derechos humanos: Nuevos tiempos, viejos retos, Bogotá, D.C.: Dejusticia, 2015. p. 230-275.

SCHWANTES, Susanna; STARCK, Gilberto. Marco temporal e as violações aos direitos dos povos indígenas: Análise da constitucionalidade e da convencionalidade a partir da jurisprudência da CIDH. Anuário Brasileiro de Direito Internacional, v. 23, n. 2, p. 148-173, 2018.

SHELTON, Dinah. The Inter-American Human Rights law of indigenous peoples. Harvard Law Review, Cambridge, v. 35, p. 937-980, 2013.

Sikkink, Kathryn; Walling, Carrie Booth. The impact of human rights trials in Latin America. Journal of Peace Research, v. 44, n. 4, p. 427-445, 2007.

TAULI-CORPUS, Victoria. Report of the Special Rapporteur of the Human Rights Council on the rights of indigenous peoples. Sept. 2018. Available at: http://unsr.vtaulicorpuz.org/ site/index.php/en/documents/annual-reports/256report-ga2018 Access on: 27 Nov. 2018.

VALENTE, Jonas. Corte Interamericana responsabiliza Brasil por desrespeito a direitos indígenas. Agencia Brasil, Mar. 2018. Available at: http://agenciabrasil.ebc.com. br/direitos-humanos/noticia/2018-03/corte-interamericana-responsabiliza-brasil-por-desrespeitar. Access on: 27 Nov. 2018. 
Para publicar na Revista de Direito Internacional, acesse o endereço eletrônico www.rdi.uniceub.br ou www.brazilianjournal.org.

Observe as normas de publicação, para facilitar e agilizar o trabalho de edição. 